\title{
Rapid synthetic approaches to libraries of diversified 1,2-dihydrochromeno[2,3-c]pyrrole-3,9-diones and 3-(2-hydroxyphen yl)-4,5-dihydropyrrolo[3,4-c]pyrazol-6(1H)-ones
}

\author{
Roman N. Vydzhak ${ }^{1}$ - Svitlana Ya. Panchishin ${ }^{1} \cdot$ Maryna V. Kachaeva ${ }^{1} \cdot$ Stepan G. Pilyo ${ }^{1}$ - Viktoriia S. Moskvina ${ }^{1,2}$. \\ Olga V. Shablykina ${ }^{1,2} \cdot$ Andriy V. Kozytskiy $^{3,4} \cdot$ Volodymyr S. Brovarets $^{1}$
}

Received: 22 March 2021 / Accepted: 12 May 2021 / Published online: 4 June 2021

(C) The Author(s), under exclusive licence to Springer Nature Switzerland AG 2021

\begin{abstract}
An efficient and practical synthetic procedure for libraries of diversified 1,2-dihydrochromeno[2,3-c]pyrrole-3,9-diones using a multicomponent process is presented. A convenient synthetic procedure for obtaining functionalized 3-(2-hydroxyphenyl)4,5-dihydropyrrolo[3,4-c]pyrazol-6(1H)-ones via ring-opening strategy has also been developed. This protocol was found to be compatible with a wide range of substituents and paves the way for the practical synthesis of title compounds with a broad range of substituents under mild condition. The products can be easily isolated by crystallization without the use of chromatography.
\end{abstract}

Graphic abstract<smiles>[R][X]c1ccc(O)c(C(=O)CC(=O)C(=O)OC)c1</smiles>

9 examples<smiles>O=CCBr</smiles>

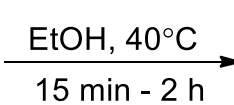

$\mathrm{H}_{2} \mathrm{~N}-$ Alk<smiles>[R][X]C1c2c(oc3ccccc3c2=O)C(=O)N1[AlH2]</smiles>

223 examples (92\% success rate)

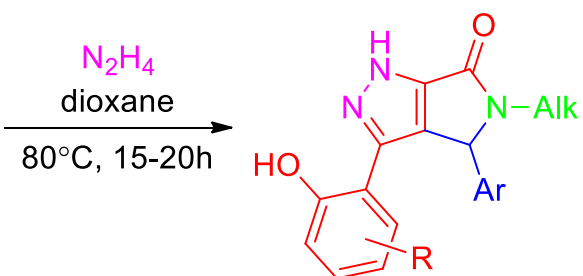

223 examples $(100 \%$ success rate)

mild and simple reaction conditions

one-pot multicomponent reaction

wide substrate scope

high purity products, no chromatography

synthetically and pharmaceutically useful molecules

Keywords Multicomponent cyclization · Combinatorial library · Dihydrochromeno[2,3-c]pyrrole-3,9-diones ·

Dihydropyrrolo[3,4-c]pyrazol-6(1H)-ones $\cdot$ Chromeno[2,3-c]pyrroles

Viktoriia S. Moskvina

v.moskvina@gmail.com

Andriy V. Kozytskiy

http://www.enamine.net

V.P. Kukhar Institute of Bioorganic Chemistry and Petrochemistry of the NAS of Ukraine, 1 Murmanska St, Kyiv 02094, Ukraine
2 Taras Shevchenko National University of Kyiv, 60 Volodymyrska St, Kyiv 01033, Ukraine

3 L. V. Pisarzhevskii Institute of Physical Chemistry of the NAS of Ukraine, 31 Nauky Ave, Kyiv 03028, Ukraine

4 Enamine Ltd., 78 Chervonotkatska St, Kyiv 02094, Ukraine 


\section{Introduction}

Synthesis of privileged classes of heterocyclic compounds has become one of the prime areas of research in the field of synthetic and medicinal chemistry, as most of the biologically active compounds are derived from heterocyclic structures $[1,2]$. The diversification of heterocyclic compounds using diversity-oriented synthesis (DOS) has been proved to be an essential tool for rapid discovery of small biologically active molecules [3, 4]. Therefore, the development of a concise and efficient strategy leading to skeletal and stereochemical diversity has gained much attention in scientific communities involved in drug discovery and biomedical research $[5,6]$.

In turn, benzopyrans (chromones) are important privileged structural motifs and serve as useful templates for the design of compound libraries in the search for novel biologically important compounds [7-13]. To date, attention was mostly focused on the synthesis of 2(3)-substituted and 2,3-disubstituted chromones. In contrast, synthetic methodologies to access chromone-fused rings are scarce, especially those involving construction of chromone-fused heterocyclic compounds. Existing reviews summarize synthetic approaches to fused pyrazoles [14-16], chromone-pyrazolefused compounds [17], azachromones, azachromanones [18]. A unique pyrano[2,3-c]pyrrole bicyclic skeleton,

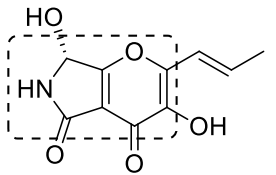

Pyranonigrin A antioxidant activity

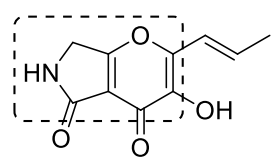

Pyranonigrin S

inhibitor of the Main protease (Mpro) of the novel SARS-CoV-2 virus

Fig. 1 Examples of the natural and useful pyrano[2,3-c]pyrroles exhibiting antioxidant activity [19-23] and rarely detected in nature, was found in Pyranonigrins-secondary metabolites produced by Aspergillus niger. Pyranonigrin A is also a potent inhibitor of the Main protease (Mpro) of the novel SARS-CoV-2 virus [24]. Compounds such as chromeno[2,3c]pyrroles were reported to behave as glucokinase activators [25] and as mimetics of glycosaminoglycans [26] (Fig. 1).

To our knowledge, the chromeno[2,3-c]pyrrole scaffold has been rarely mentioned in the literature. Our previous reports focused on the limited examples of the synthesis of chromeno[2,3-c]pyrrole derivatives via multistep condensation of methyl 4-(o-hydroxyphenyl)-2,4-dioxobutanoate [27-29] and methyl (E)-6-phenyl-2,4-dioxohex-5-enoate [30] with aromatic aldehydes and aliphatic amines or ethyl 3-bromomethyl-4-oxochromene-2-carboxylate with amines [31]. Additionally, recent papers reported the synthesis of spiro derivatives of chromeno[2,3-c]pyrrole-3,9-diones with $N$-substituted isatins used as the carbonyl component [32, $33]$. The acid-catalyzed transformation of some furo [3,4$b]$ chromones into pyrrolo[3,4- $b]$ chromones has also been reported [34-38]. The multicomponent reaction of 3-formylchromones with isocyanides and azodicarboxylates is an alternative route to the preparation of chromeno[2,3-c] pyrroles [39]. It should be noted that one-pot multicomponent reactions (MCRs) are some of the most efficient tools in modern synthetic organic chemistry for the preparation of highly functionalized organic compounds [40], including N-heterocycles [41, 42]. Moreover, they have all the features of a perfect synthetic method: high efficiency and step economy, quick and simple implementation, time and energy reductions, environmental friendliness, and suitability for target and diversity-oriented synthesis [43].

Aiming at accessing diverse privileged skeletons of chromeno[2,3-c]pyrrole, we performed rapid and efficient construction of target libraries of drug-like compounds2-alkyl-1-aryl-1,2-dihydrochromeno[2,3-c]pyrrole-3,9-diones-from relatively simple and commercial available reagents via one-pot multicomponent heterocyclization.

\section{Results and discussion}

As part of our interest in the development of combinatorial chemistry, we aimed to design a previously unreported onepot multicomponent reaction. Initially, as a model reaction,
Scheme 1 Investigation of onepot three-component reaction of 4-(2-hydroxyphenyl)-2,4-dioxobutanoate $\mathbf{1}\{1\}$, benzaldehyde $\mathbf{2}\{1\}$ and benzylamine $\mathbf{3}\{16\}$ as a model reaction

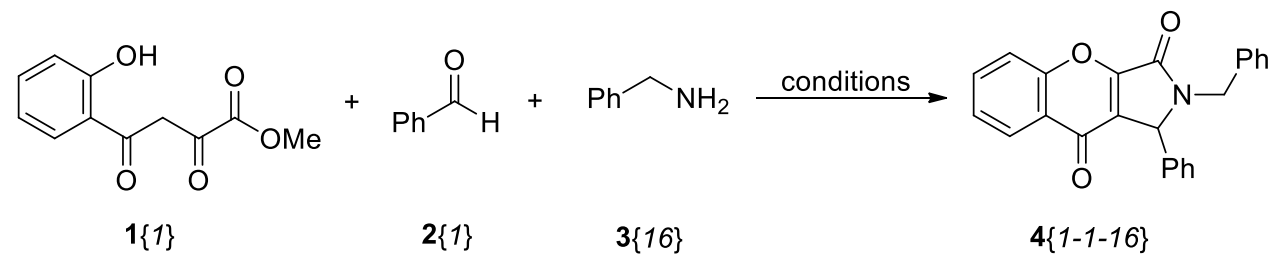


Table 1 Optimization of the reaction conditions on the example of compound 4\{1-1-16\} synthesis $^{\text {a }}$

\begin{tabular}{lllll}
\hline Entry & Solvent & $\begin{array}{l}\text { Tempera- } \\
\text { ture }\left({ }^{\circ} \mathrm{C}\right)\end{array}$ & $\begin{array}{l}\text { Reaction } \\
\text { time }(\mathrm{h})\end{array}$ & $\begin{array}{l}\text { Yield of } \\
\text { product } \\
(\%)^{\mathrm{b}}\end{array}$ \\
\hline 1 & $\mathrm{MeOH}$ & r.t & 1.5 & 24 \\
2 & $\mathrm{MeOH}$ & 40 & 1 & 36 \\
3 & EtOH & 40 & 1 & 26 \\
4 & EtOH $+\mathrm{MeC}(\mathrm{O})$ & 40 & 0.3 & 74 \\
& OH $(1 \mathrm{~mL})$ & & & \\
5 & $i$-PrOH & 40 & 1 & 42 \\
6 & THF & 40 & 2 & 17 \\
7 & acetic acid & 40 & 2 & 22 \\
8 & acetic acid & 120 & 0.5 & traces \\
\hline
\end{tabular}

${ }^{a}$ Reaction conditions: 4-(2-hydroxyphenyl)-2,4-dioxobutanoate (1.0 eq.), benzaldehyde (1.0 eq.) and benzylamine (1.0 eq.), appropriate solvent $(10 \mathrm{~mL}), \mathrm{r}$. t. or heating

${ }^{\mathrm{b}}$ Yields of isolated compound $4\{1-1-16\}$

we assessed the three-component reaction of commercially available 4-(2-hydroxyphenyl)-2,4-dioxobutanoate $\mathbf{1}\{1\}$, benzaldehyde $2\{1\}$ and benzylamine $\mathbf{3}\{16\}$, to survey key parameters for one-pot process (Scheme 1). We first tested the reaction of starting reagents $(\mathbf{1}\{1\}, \mathbf{2}\{1\}$ and $\mathbf{3}\{16\})$ in the presence of different solvents to optimize the reaction conditions (Table 1). Indeed, upon interaction of the starting reagents in a molar ratio of 1:1:1 in $10 \mathrm{~mL}$ of absolute $\mathrm{MeOH}$ at room temperature for $1.5 \mathrm{~h}$, the reaction gave 2-benzyl-1-phenyl-1,2-dihydrochromeno[2,3-c]pyrrole3,9 -dione $(4\{1-1-16\})$ as the only product with a yield of $24 \%$ (Entry 1, Table 1). When the reaction was repeated at $40{ }^{\circ} \mathrm{C}$, the same product $4\{1-1-16\}$ was obtained in the higher yield of 36\% (Entry 2, Table 1). The reaction was repeated in $\mathrm{EtOH}$ and in $\mathrm{EtOH}$ with addition of $1 \mathrm{~mL}$ of acetic acid at $40{ }^{\circ} \mathrm{C}$, which resulted in $4\{1-1-16\}$ with yields of $26 \%$ and $74 \%$, respectively (Entry 3 and 4 , Table 1 ). The product 4\{1-1-16\} also formed in low yields when using $i$-PrOH ( $42 \%$ yield of the product), THF (17\% yield of the product) and acetic acid (22\% yield of the product) at $40{ }^{\circ} \mathrm{C}$ (Entry 5-7, Table 1). It is noteworthy that in acetic acid under reflux, 4\{1-1-16\} was obtained in trace amounts in a complex mixture of unidentified products (Entry 8, Table 1). Overall, in almost all cases the yields of the key product were not high. Thus, the best approach (primarily based on the yield of the key reaction product) was to carry out the reaction in absolute EtOH with the addition of acetic acid at $40{ }^{\circ} \mathrm{C}$, which completed in $30 \mathrm{~min}$ (Entry 4, Table 1). We also noted that when the reaction was carried out under these conditions with molar ratios of the starting reagents of $1: 1.2: 1.2$ or $1: 1.5: 1.5$, the product $4\{1-1-16\}$ formed with moderate yields (up to $36 \%$ ) together with unidentified mixtures of complex products.

Based on the results of reaction optimization, we propose the following mechanism for this one-pot three-component reaction (Scheme 2). The condensation of starting compounds occurs under basic conditions and gives an adduct $\mathbf{A}$, which is then converted into 1-alkyl-5-aryl-4-(2hydroxybenzoyl)-3-hydroxy-2,5-dihydro- $1 H$-pyrrol-2-one B. Subsequent dehydration of $\mathbf{B}$ results in the product 4 . The dehydration is more effective in acidic medium; addition of $1 \mathrm{~mL}$ of acetic acid was sufficient to increase the yield, while adding bigger amounts resulted in higher reaction temperature and resulted in noticeably smaller yields.
Scheme 2 Mechanism of compound 4 synthesis

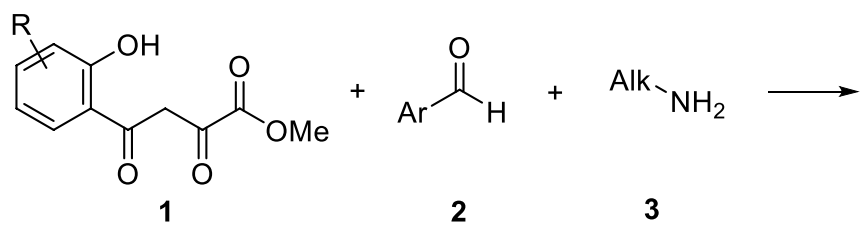<smiles>[R]c1cccc(C[Al]C2C(C(=O)c3cccc([R])c3O)=C(O)C(=O)N2[Al])c1O</smiles>

Scheme 3 1-aryl1,2-dihydrochromeno[2,3-c] pyrrole-3,9-diones 4 library generation

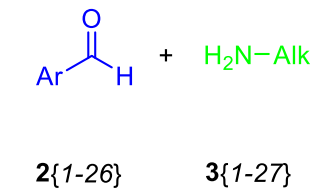

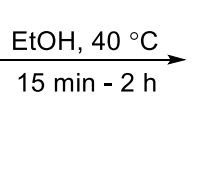

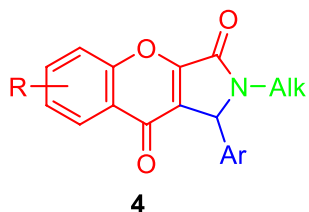


With the optimized reaction conditions in hand, we set out to explore the use of substituted methyl 4-(o-hydroxyphenyl)-2,4-dioxobutanoates 1\{1-9\} (9 examples), aryl aldehydes $2\{1-26\}$ (26 examples) and primary amines $3\{1-27\}$ (27 examples) in the obtainment of a variety of 2-alkyl-1-aryl-1,2-dihydrochromeno[2,3-c]pyrrole-3,9-diones 4 in a one-pot multicomponent reaction (Scheme 3).

The representative substrates-methyl 4-(o-hydroxyphenyl)-2,4-dioxobutanoates 1\{1-9\}, aryl aldehydes $2\{1-26\}$ and primary amines $3\{1-27\}$-are listed in Fig. 2. First, the compatibility of different aryl aldehydes and primary amines in these multicomponent heterocyclization was examined. To our delight, a wide range of alkyl groups in the case of aryl aldehydes $2\{1-26\}$, including methoxy, methyl, ethyl, propyl, butyl, allyl, benzyl and halogen, were well compatible in this transformation. The electronic effects of substituents had little influence on the cyclization. Note that a small excess of amines (1.1 eq.) was used in the interaction of aldehydes with a phenolic hydroxyl group. It should be mentioned that the substituted primary amines were also suitable for the transformation and synthesis of 2-alkyl-1-aryl-1,2-dihydrochromeno[2,3c]pyrrole-3,9-diones 4. But longer heating (up to 2 h) was required when using aldehydes with donor groups and shorter heating (15-20 min) when using aldehydes with acceptor groups. Methyl 4-(o-hydroxyphenyl)-2,4-dioxobutanoates with methyl, chloro and fluoro substituents were also tolerated in this one-pot multicomponent procedure, demonstrating the generality of the method. As a result, 223 out of 240 experiments allowed us to obtain the target 1,2-dihydrochromeno[2,3-c]pyrrole-3,9-diones (92\% success rate) with good purity ( $>95 \%$ according to HPLC). In most cases, yields were in the $43-86 \%$ range, and for more than $50 \%$ of the representative set, the yield was more than $70 \%$.

Chromones are widely used as excellent matrices for performing structural modifications allowing the synthesis of a wide range of compounds with different pharmacological profiles, which is certainly interesting for drug discovery [44-48]. Thus, the incorporation of pyrazole motif into the heterocyclic systems has led to important scaffolds attracted the attention of both industrial and medicinal chemists [44]. To demonstrate further the synthetic utility of the obtained 2-alkyl-1-aryl-1,2-dihydrochromeno[2,3-c]pyrrole-3,9-diones 4, we developed ring-opening strategy with hydrazine hydrate, provides a wide scope of differently substituted pyrrolopyrazolones.

Initially, the recyclization of 2-methyl-1-phenyl1,2-dihydrochromeno[2,3-c]pyrrole-3,9-dione 4\{3-1-2\} with hydrazine hydrate was examined (Scheme 4). We first tested the known literature method used for the recyclization of benzopyran-4-ones with hydrazine hydrate [17]. For compound 4\{3-1-2\} as a model compound, it was found that recyclization under the action of hydrazine hydrate proceeded in $\mathrm{EtOH}$ at different molar ratios of the starting reagents (from 1: 1 to $1: 3$ ); however, the yields of the target product were rather low-up to $18 \%$ when the reaction was carried out at room temperature and not exceeding $30 \%$ at $80{ }^{\circ} \mathrm{C}$. To increase the yield of the final product, an optimization of the reaction conditions was carried out. We varied the solvent, temperature, ratio of the reagents. The results obtained from the optimization are shown in Table 2. It should be noted that the yield of the target product 5 $53-1-2\}$ increased, and the reaction completion time decreased with an increase in the reaction temperature in both $\mathrm{EtOH}$ and dioxane, and with an increase in the molar ratio of the starting reagents (Entry 1-3 and 5-7). However, the reaction with the molar ratio of 1: 7 gave the product with a lower yield, and a complex mixture of unidentified products containing pyrazolecarboxylic acid hydrazide (Entry 4 and 8 ) was observed in the reaction mixture. Fairly efficient reaction conditions were found to be the use of the starting reagents in a molar ratio of 1: 5 in dioxane at $40{ }^{\circ} \mathrm{C}$ (Entry 7). An increase in the reaction temperature to $80{ }^{\circ} \mathrm{C}$ resulted in the lower yield $(56 \%)$ of the product $5\{3-1-2\}$ in $4-6 \mathrm{~h}$ (Entry 9 ) due to the formation of a complex mixture of unidentified products. Finally, the product 5 $\{3-1-2\}$ was obtained with $78 \%$ yield when the reaction mixture was kept in dioxane at $80{ }^{\circ} \mathrm{C}$ for $20 \mathrm{~h}$ (Entry 10 ); notably, despite a noticeable amount of intermediate products being observed in the ${ }^{1} \mathrm{H}$ NMR spectra of the reaction mixture after 4 and $12 \mathrm{~h}$, only one key product was detected after $20 \mathrm{~h}$.

Under the optimized conditions, a series of substituted 3-(2-hydroxyphenyl)-4,5-dihydropyrrolo[3,4-c]pyrazol$6(1 H)$-one $(5)$ were synthesized in a $20-\mathrm{mL}$ glass vial using 1:5 molar ratio of chromeno[2,3-c]pyrrole-3,9-diones and hydrazine hydrate in dioxane by operationally simple procedure (Scheme 5). The wide availability of 1,2-dihydrochromeno[2,3-c]pyrrole-3,9-diones makes the developed synthetic protocol a powerful tool for achieving a great variety of final products-4,5-dihydropyrrolo[3,4c] pyrazol-6(1H)-ones $\mathbf{5}$.

As a result, 223 experiments allowed us to obtain the target 4,5-dihydropyrrolo[3,4-c]pyrazol-6(1H)-ones $(100 \%$ success rate) and with good purity (>95\% according HPLC). In most cases, yields were in the $72-94 \%$ range, and for $50 \%$ of the representative set, the yield was more than $80 \%$.

The correlation of proton signals in ${ }^{1} \mathrm{H}$ NMR spectra of chromeno[2,3-c]pyrrole-3,9-diones can be in most cases performed quite easily based on signal multiplicity, but the appearance of the ${ }^{13} \mathrm{C}$ NMR spectra was less predictable. The use of two-dimensional NMR spectroscopy methods on substance $4\{3-1-2\}$ made it possible to not only confirm the shown structure, but also to accurately identify the range of characteristic signals of the chromeno[2,3-c] 
<smiles>COC(=O)C(=O)CC(=O)c1ccccc1O</smiles><smiles>COC(=O)C(=O)CC(=O)c1ccc(C)cc1O</smiles><smiles>COC(=O)C(=O)CC(=O)c1cc(C)ccc1O</smiles><smiles>COC(=O)C(=O)CC(=O)c1cc(C)cc(C)c1O</smiles><smiles>COC(=O)C(=O)CC(=O)c1cc(C)c(C)cc1O</smiles><smiles>COC(=O)C(=O)CC(=O)c1c(C)cc(C)cc1O</smiles><smiles>COC(=O)C(=O)CC(=O)c1cc(F)ccc1O</smiles><smiles>COC(=O)C(=O)CC(=O)c1cc(Cl)ccc1O</smiles><smiles>COC(=O)C(=O)CC(=O)c1cc(Cl)c(C)cc1O</smiles><smiles>O=Cc1ccccc1</smiles><smiles>Cc1ccc(C=O)cc1</smiles>
$2\{2\}$<smiles>CCc1ccc(C=O)cc1</smiles>

$2\{3\}$<smiles>CCCc1ccc(C=O)cc1</smiles>

$2\{4\}$<smiles>O=Cc1cccc(O)c1</smiles>

$2\{5\}$<smiles>CCCCOc1cccc(C=O)c1</smiles>

$2\{6\}$<smiles>O=Cc1cccc(OC(=O)O)c1</smiles>

2\{7\}<smiles>O=Cc1cccc(O)c1</smiles>

$2\{8\}$<smiles>C=CCOc1cccc(C=O)c1</smiles>

$2\{9\}$<smiles>C=CCc1ccc(C=O)cc1OC</smiles><smiles>COc1ccc(C=O)cc1</smiles><smiles>O=Cc1ccc(O)cc1</smiles><smiles>C=CCOc1ccc(C=O)cc1</smiles><smiles>O=Cc1ccc(Oc2ccccc2)cc1</smiles><smiles>COc1ccc(O)cc1</smiles><smiles>C=CCOc1ccc(C=O)cc1OC</smiles><smiles>CCOc1ccc(C=O)cc1O</smiles><smiles>COc1cc(C=O)cc(OC)c1OC</smiles><smiles>O=Cc1ccccc1F</smiles><smiles>O=Cc1ccc(Cl)cc1</smiles><smiles>O=Cc1ccc(Br)cc1</smiles><smiles>O=Cc1ccc(Cl)c(Cl)c1</smiles><smiles>COc1ccc(C=O)cc1</smiles><smiles>O=Cc1ccc([N+](=O)[O-])cc1</smiles><smiles>CCNCCN</smiles>

$2\{21\}$

$2\{22\}$

$2\{23\}$

$2\{24\}$

$2\{25\}$

$2\{26\}$
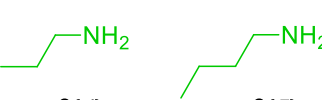

$=\overbrace{}^{\mathrm{NH}_{2}}$

$3\{5\}$

$3\{6\}$

$3\{7\}$

$\mathrm{NH}_{2}$

$3\{4\}$

(1)

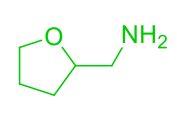

$3\{13\}$

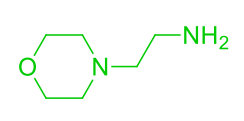

$3\{12\}$

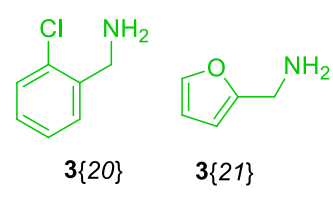<smiles>NCc1cccnc1</smiles>

$3\{22\}$
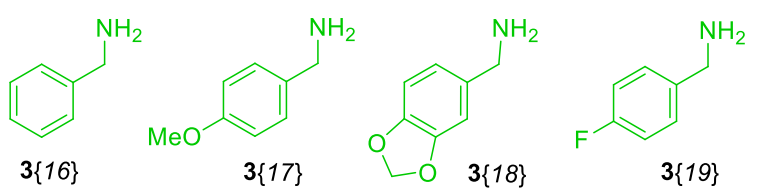

$3\{20\}$

$3\{21\}$

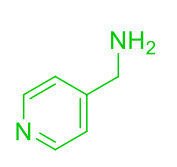

$3\{23\}$

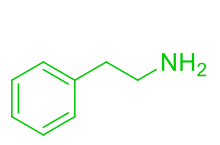

$3\{24\}$

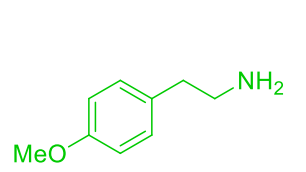

$3\{25\}$

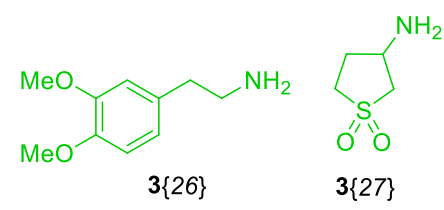

Fig. 2 Scope of 4-(2-hydroxyphenyl)-2,4-dioxobutanoates $\mathbf{1}\{1-9\}$, aryl aldehydes $2\{1-26\}$ and primary amines $3\{1-27\}$ 
Scheme 4 Investigation of recyclization of model compound $(4\{3-1-2\})$ with hydrazine hydrate

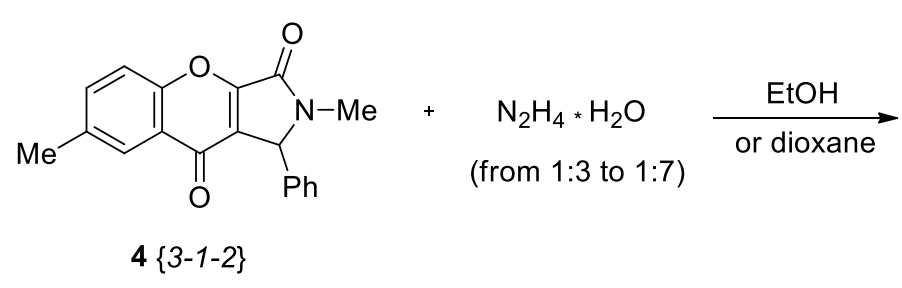<smiles>Cc1ccc(O)c(-c2n[nH]c3c2C(c2ccccc2)N(C)C3=O)c1</smiles>

Table 2 Optimization of the reaction conditions on the example of compound 5 $53-1-2\}$ synthesis $^{\mathrm{a}}$

\begin{tabular}{llllll}
\hline Entry & $\begin{array}{l}\text { Molar ratio of reagents } \\
\mathbf{4}\{-1-2\}: \text { hydrazine hydrate }\end{array}$ & Solvent & $\begin{array}{l}\text { Temperature } \\
\left({ }^{\circ} \mathrm{C}\right)\end{array}$ & $\begin{array}{l}\text { Reaction time } \\
(\mathrm{h})\end{array}$ & $\begin{array}{l}\text { Yield of } \\
\text { product } \\
(\%)^{\mathrm{b}}\end{array}$ \\
\hline 1 & $1: 3$ & EtOH & r. t & 6 & 18 \\
2 & $1: 3$ & EtOH & 80 & 6 & 30 \\
3 & $1: 5$ & EtOH & 80 & 4 & 42 \\
4 & $1: 7$ & EtOH & 80 & 3 & 31 \\
5 & $1: 3$ & Dioxane & r. t & 4 & 32 \\
6 & $1: 3$ & Dioxane & 40 & 4 & 34 \\
7 & $1: 5$ & Dioxane & 40 & 4 & 64 \\
8 & $1: 7$ & Dioxane & 40 & $4-5$ & 38 \\
9 & $1: 5$ & Dioxane & 80 & $4-6$ & 56 \\
10 & $1: 5$ & Dioxane & 80 & 20 & 78 \\
\hline
\end{tabular}

${ }^{a}$ Reaction conditions: 2-methyl-1-phenyl-1,2-dihydrochromeno[2,3-c]pyrrole-3,9-dione (1.0 eq.) with hydrazine hydrate (3.0 eq. or 5 eq., or 7 eq.), appropriate solvent $(10 \mathrm{~mL})$, heating

${ }^{b}$ Yields of isolated compound $\mathbf{5}\{3-1-2\}$<smiles>[R]#Cc1cccc2c(=O)c3c(oc12)C(=O)N([AlH2])C3Br</smiles>

(1 eq.)<smiles>[R]c1cccc(O)c1-c1n[nH]c2c1C([Al])N([Al])C2=O</smiles>

5

Scheme 5 3-(2-hydroxyphenyl)-4,5-dihydropyrrolo[3,4-c]pyrazol-6(1H)-ones 5 library generation

pyrrole-3,9-dione system in ${ }^{13} \mathrm{C}$ NMR spectra. The signal of $\gamma$-pyrone carbonyl group's carbon is observed in the weakest field (more than $170 \mathrm{ppm}$ ); the carbon signal of the pyrrolone carbonyl group is observed in the field around $160 \mathrm{pm}$ which is characteristic for amide groups. The carbon signal of the methine fragment of pyrrolone in the studied substance was slightly more than $60 \mathrm{ppm}$, although the spectra of some other derivatives, especially those with alkoxy groups, show other signals in the same region. For two-dimensional NMR experiments, $\mathrm{CF}_{3} \mathrm{COOD}$ was used because $4\{3-1-2\}$ is significantly higher solvable in it than in DMSO- $d_{6}$; however, a comparison with the spectra taken in DMSO- $d_{6}$ shows insignificant difference in chemical shifts. Figure 3 shows the assignments and the most important $\mathrm{HMBC}$ correlations (black doted) and NOESY correlations (red) for 4\{3-1-2\}.

As expected, ${ }^{1} \mathrm{H}$ NMR spectra in DMSO- $d_{6}$ show a significant high-field shift of protons of 2-hydroxyphenyl moiety of 4,5-dihydropyrrolo[3,4-c]pyrazol-6(1H)ones (5) compared to protons of chromone fragment of chromeno[2,3-c]pyrrole-3,9-diones (4). With no other substituents present, signals of the corresponding protons are located at 7.5-8.1 ppm for products 4 and at $6.7-7.5 \mathrm{ppm}$ for products 5 . However, ${ }^{13} \mathrm{C}$ NMR spectra in DMSO- $d_{6}$ of compounds 5 do not allow to identify carbon atoms of the pyrazole ring because of quick tautomeric transformations of pyrazole, and due to the weak intensity of the most lowfield carbon atom of the pyrrolone carbonyl group, located 


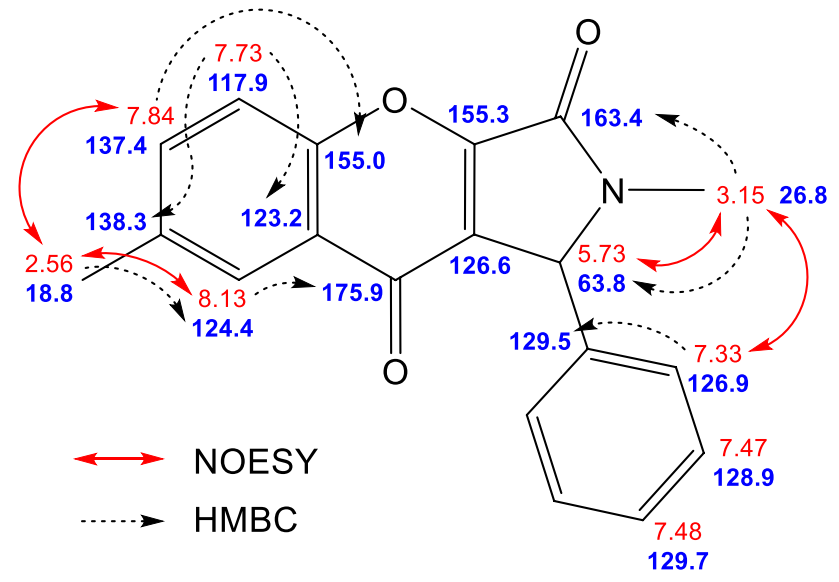

Fig. 3 Important HMBC and NOESY correlations for $4\{3-1-2\}$ $\left(\mathrm{CF}_{3} \mathrm{COOD}\right)$

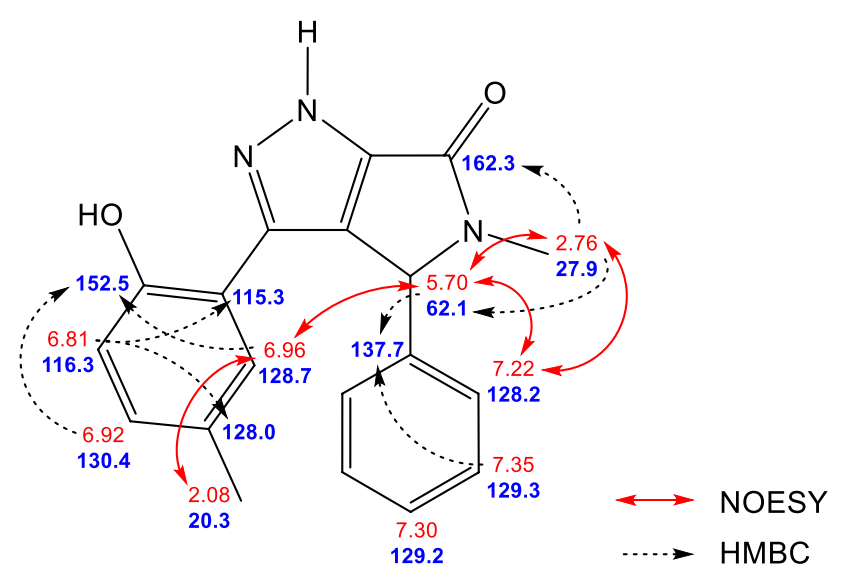

Fig. 4 Important HMBC and NOESY correlations for $5\{3-1-2\}$ $\left(\mathrm{DMSO}-d_{6}\right)$

at around $162 \mathrm{ppm}$. In particular, in the spectra of 5\{3-12 \} it was only found due to correlations with the signals of the methine and $\mathrm{N}$-methyl fragments. Assignment of pyrazole ring carbon atoms is possible when $\mathrm{CF}_{3} \mathrm{COOD}$ is used as a solvent; however, protonation causes wider signals in ${ }^{1} \mathrm{H}$ NMR spectra. As an example, the product 5 $\{3-1-2\}$ 's ${ }^{1} \mathrm{H}$ and ${ }^{13} \mathrm{C}$ NMR spectral data in DMSO$d_{6}$ and $\mathrm{CF}_{3} \mathrm{COOD}$ is provided in the experimental part. Figure 4 shows the assignments and the most important HMBC correlations (black doted) and NOESY correlations (red) for 5 $53-1-2\}$.

The IR spectra of products 4 contain fairly intense absorption bonds of carbonyl groups at $1717-1701 \mathrm{~cm}^{-1}$ and $1668-1647 \mathrm{~cm}^{-1}$, as well as rather intensive absorption of the unsaturated fragments conjugated with them, at approximately $1610 \mathrm{~cm}^{-1}$.

The higher-frequency absorption band is associated, evidently, with the carbonyl group of the chromone fragment, since there is no absorption in this region in the IR spectra of the recyclization products $\mathbf{5}$. At the same time, the amide band in the $1660-1690 \mathrm{~cm}^{-1}$ region remains very intense, partially overlapping with the absorption band of conjugated multiple bonds (approximately $1620 \mathrm{~cm}^{-1}$ ). The high acidity of the $\mathrm{O}-\mathrm{H}$ and $\mathrm{N}-\mathrm{H}$ bonds in pyrrolopyrazoles 5 causes a very broad absorption in the $3500-2500 \mathrm{~cm}^{-1}$ range.

\section{Conclusion}

In conclusion, we have developed a new one-pot version of a multicomponent reaction for the synthesis of libraries of functional 1,2-dihydrochromeno[2,3-c] pyrrole-3,9-diones based on the interaction of methyl 4-(o-hydroxyphenyl)-2,4-dioxobutanoates, aryl aldehydes and primary amines. The possibility of using the obtained 1,2-dihydrochromeno[2,3-c]pyrrole-3,9-diones for the synthesis of functional 3-(2-hydroxyphenyl)4,5-dihydropyrrolo[3,4-c]pyrazol-6(1H)-ones was demonstrated. This protocol was found to be compatible with a wide range of substituents and paves the way for the practical synthesis of title compounds with a broad range of substituents under mild condition. The two synthetic techniques developed by this work are of interest for the synthesis of complex heterocyclic structures with possible biological activity. The resulting two libraries of compounds-1,2-dihydrochromeno-[2,3-c]pyrrole-3,9-diones (223 examples) and 3-(2-hydroxyphenyl)-4,5-dihydro-pyrrolo[3,4-c]pyrazol-6(1H)-ones (223 examples) - represent a real opportunity for the discovery of new drug candidates. Our group is currently investigating these potential applications, and the results will be published in due course.

\section{Experimental}

\section{General remarks}

The solvents were purified according to the standard procedures. All materials were purchased from commercial sources and used without further purification. Reaction flow and identity of obtained compounds were controlled with TLC on Merck $\mathrm{F}_{254}$ plates using chloroform: methanol (9:1, $v / v)$ system as eluents. The success rate was calculated as the number of successful experiments divided by the total number of experiments. ${ }^{1} \mathrm{H}$ NMR spectra were recorded on a Varian VXR-300 spectrometer (300 MHz) or Bruker 170 spectrometer $(500 \mathrm{MHz})$, and ${ }^{13} \mathrm{C}$ NMR spectra were recorded at Bruker 170 spectrometer $(125 \mathrm{MHz})$ spectra in DMSO- $d_{6}$ or $\mathrm{CF}_{3} \mathrm{COOD}$, or $\mathrm{CDCl}_{3}$ solution. Chemical shifts are reported in ppm downfield from TMS as internal standards. Mass spectra were recorded on an LC-MS instrument 
with chemical ionization (CI). LC-MS data were acquired on an Agilent 1200 HPLC system equipped with DAD/ ELSD/LCMS-6120 diode matrix and mass-selective detector. Melting points were measured on a MPA100 OptiMelt automated melting point system.

Combustion elemental analysis was performed by hand in the V.P. Kukhar Institute of Bioorganic Chemistry and Petrochemistry analytical laboratory. The carbon and hydrogen contents were determined using the Pregl gravimetric method, nitrogen-using the Duma's gasometrical micromethod, sulfur-by the Scheininger titrimetric method, chlorine-by the mercurometric method.

Experimental Section describes 25 compounds selected in random manner, which corresponds to generally accepted approaches in combinatorial chemistry (according to ACS standards).

\section{General procedure for the synthesis of 1-aryl-1,2-di hydrochromeno[2,3-c]pyrrole-3,9-diones 4}

To a solution of $0.01-0.011 \mathrm{~mol}$ of aryl aldehyde $2\{1-26\}$ in $10-15 \mathrm{~mL}$ of dry EtOH, 0.01-0.011 mol of primary amine $3\{1-27\}$ was added at room temperature and mixture was stirred for $0.3 \mathrm{~h}$. Then, $0.01 \mathrm{~mol}$ of methyl $o$-hydroxybenzoylpyruvate 1\{1-9\} was added. The mixture was heated at $40{ }^{\circ} \mathrm{C}$ for $15-20 \mathrm{~min}$, and $1 \mathrm{~mL}$ acetic acid was added. The resulting mixture was refluxed at $80^{\circ} \mathrm{C}$ for $20 \mathrm{~h}$; the reaction progress was monitored with TLC. After the completion of the reaction, the mixture was allowed to cool down to rt, and precipitate was filtered off (in most cases) or concentrated under vacuum and the residues were purified by crystallized from ethanol.

2 - (Pyridin-4-ylmethyl) - 1-(p-tolyl)-1,2dihydrochromeno[2,3-c]pyrrole-3,9-dione (4\{1-2-23\}) Yield: 70\%; mp 220-223 ${ }^{\circ} \mathrm{C}$; IR (KBr): 2902, 1715 (C=O), $1656(\mathrm{C}=\mathrm{O}), 1611,1462,1403,1273,1208,1174,894,860$, $822,759,556,534 \mathrm{~cm}^{-1} .{ }^{1} \mathrm{H}$ NMR (400 MHz, DMSO- $\left.d_{6}\right) \delta$ $8.45(\mathrm{~d}, J=5.8 \mathrm{~Hz}, 2 \mathrm{H}), 8.03(\mathrm{~d}, J=8.3 \mathrm{~Hz}, 1 \mathrm{H}), 7.95-7.85$ (m, 2H), 7.55 (ddd, $J=8.0,5.6,2.6 \mathrm{~Hz}, 1 \mathrm{H}), 7.23-7.15$ (m, 4H), 7.13 (d, J=7.9 Hz, 2H), 5.57 (s, 1H), 4.85 (d, $J=16.4 \mathrm{~Hz}, 1 \mathrm{H}), 4.03(\mathrm{~d}, J=16.4 \mathrm{~Hz}), 2 \mathrm{H}, 2.27(\mathrm{~s}, 3 \mathrm{H}) .{ }^{13} \mathrm{C}$ NMR (100 MHz, DMSO- $\left.d_{6}\right): \delta 173.1,162.2,156.5,155.0$, $150.1,145.8,138.8,135.5,130.9,129.9,128.6,128.0$, 126.7, 125.7, 125.4, 122.9, 119.7, 60.2, 43.5, 21.2. APSI MS: $383.2\left(\mathrm{M}^{+}+1\right)$. Anal. Calcd for $\mathrm{C}_{24} \mathrm{H}_{18} \mathrm{~N}_{2} \mathrm{O}_{3}$ : C, 75.38; $\mathrm{H}, 4.74$; N, 7.33\%. Found: C, 75.35; H, 4.79; N, 7.39\%.

1 - (4 - (A l lyloxy) phe nyl) - 2 - methy $l$ 1,2-dihydrochromeno[2,3-c]pyrrole-3,9-dione (4\{1-14-2\}) Yield: 66\%; mp 202-205 ${ }^{\circ} \mathrm{C}$; IR (KBr): 2919, 1711 (C=O), $1657(\mathrm{C}=\mathrm{O}), 1609,1514,1460,1419,1391,1258,1177$, 1098, 896, 831, 758, 690, $565 \mathrm{~cm}^{-1}$. ${ }^{1} \mathrm{H}$ NMR (400 MHz, DMSO- $\left.d_{6}\right) \delta 8.03(\mathrm{~d}, J=7.9 \mathrm{~Hz}, 1 \mathrm{H}), 7.92-7.81(\mathrm{~m}, 2 \mathrm{H})$, $7.54(\mathrm{t}, J=7.1 \mathrm{~Hz}, 1 \mathrm{H}), 7.26(\mathrm{~d}, J=6.8 \mathrm{~Hz}, 2 \mathrm{H}), 6.94(\mathrm{~d}$,
$J=6.8 \mathrm{~Hz}, 2 \mathrm{H}), 6.10-5.96(\mathrm{~m}, 1 \mathrm{H}), 5.56(\mathrm{~s}, 1 \mathrm{H}), 5.39$ (d, $J=17.3 \mathrm{~Hz}, 1 \mathrm{H}), 5.24$ (d, $J=10.4 \mathrm{~Hz}, 1 \mathrm{H}), 4.59-4.51$ $(\mathrm{m}, 2 \mathrm{H}), 2.79(\mathrm{~s}, 3 \mathrm{H}) .{ }^{13} \mathrm{C}$ NMR (100 MHz, DMSO- $\left.d_{6}\right)$ : $\delta 161.5,158.9,156.4,155.4,135.3,134.1,129.6,127.6$, 126.6, 126.2, 125.7, 125.4, 119.7, 118.0, 115.4, 68.7, 60.9, 27.7. APSI MS: $348.2\left(\mathrm{M}^{+}+1\right)$. Anal. Calcd for $\mathrm{C}_{21} \mathrm{H}_{17} \mathrm{NO}_{4}$ : C, 72.61; H, 4.93; N, 4.03\%. Found: C, 72.64; H, 4.90; N, $4.12 \%$.

1-(2-Fluorophenyl)-2-propyl-1,2-dihydrochromeno[2,3c]pyrrole-3,9-dione $(4\{1-20-4\})$ Yield: $67 \%$; mp 210-215 ${ }^{\circ} \mathrm{C}$; IR (KBr): 2934, $1706(\mathrm{C}=\mathrm{O}), 1655(\mathrm{C}=\mathrm{O})$, 1610, 1489, 1408, 1288, 1225, 1173, 1106, 757, $689 \mathrm{~cm}^{-1}$. ${ }^{1} \mathrm{H}$ NMR (400 MHz, DMSO- $\left.d_{6}\right) \delta 8.05(\mathrm{~d}, J=7.9 \mathrm{~Hz}, 1 \mathrm{H})$, $7.94-7.82(\mathrm{~m}, 2 \mathrm{H}), 7.55(\mathrm{t}, J=7.3 \mathrm{~Hz}, 1 \mathrm{H}), 7.47-7.33(\mathrm{~m}$, 2H), 7.30-7.14 (m, 2H), $5.90(\mathrm{~s}, 1 \mathrm{H}), 3.67-3.53(\mathrm{~m}, 1 \mathrm{H})$, $2.85(\mathrm{dt}, J=13.7,6.7 \mathrm{~Hz}, 1 \mathrm{H}), 1.61-1.34(\mathrm{~m}, 2 \mathrm{H}), 0.80(\mathrm{t}$, $J=7.4 \mathrm{~Hz}, 3 \mathrm{H}) .{ }^{13} \mathrm{C} \mathrm{NMR}\left(100 \mathrm{MHz}, \mathrm{DMSO}-d_{6}\right): \delta 172.9$, $161.7,161.4(\mathrm{~d}, J=247.2 \mathrm{~Hz}), 156.4,155.4,135.4,131.4$ $(\mathrm{d}, J=8.5 \mathrm{~Hz}), 126.9,126.7,125.7,125.5(\mathrm{~d}, J=3.2 \mathrm{~Hz})$, $125.1,121.2(\mathrm{~d}, J=11.8 \mathrm{~Hz}), 119.7,116.3(\mathrm{~d}, J=21.4 \mathrm{~Hz})$, 42.6, 21.4, 11.5. APSI MS: $338.0\left(\mathrm{M}^{+}+1\right)$. Anal. Calcd for $\mathrm{C}_{20} \mathrm{H}_{16} \mathrm{FNO}_{3}$ : C, 71.21; H, 4.78; N, 4.15\%. Found: C, 71.24; $\mathrm{H}, 4.75$; N, $4.26 \%$.

1-(3,4-Dichlorophenyl)-2-(1,1-dioxidotetrahydrothiophen-3-yl)-1,2-dihydro-chromeno[2,3-c]pyrrole-3,9-dione (4\{1-24-27\}) Yield: 71\%; mp 200-202 ${ }^{\circ} \mathrm{C}$; IR (KBr): 3558, 2951, $1717(\mathrm{C}=\mathrm{O}), 1668(\mathrm{C}=\mathrm{O}), 1608,1463,1402,1365$, $1313,1267,1203,1122,755,570 \mathrm{~cm}^{-1}$. Two diastereomers. ${ }^{1} \mathrm{H}$ NMR (400 MHz, DMSO- $\left.d_{6}\right) \delta 8.01(\mathrm{~d}, J=7.7 \mathrm{~Hz}$, $1 \mathrm{H}), 7.93-7.84(\mathrm{~m}, 3 \mathrm{H}), 7.63(\mathrm{dd}, J=8.3,5.2 \mathrm{~Hz}, 1 \mathrm{H})$, 7.59-7.48 (m, 2H), $5.93(\mathrm{~s}, 0.5 \mathrm{H}), 5.86(\mathrm{~s}, 0.5 \mathrm{H}), 4.54-4.41$ $(\mathrm{m}, 0.5 \mathrm{H}), 4.37-4.23(\mathrm{~m}, 0.5 \mathrm{H}), 3.61(\mathrm{dd}, J=12.9,10.6 \mathrm{~Hz}$, $0.5 \mathrm{H}), 3.46-3.25\left(\mathrm{~m}, 2 \mathrm{H}\right.$ with $\left.\mathrm{H}_{2} \mathrm{O}\right), 3.19-3.04(\mathrm{~m}, 1.5 \mathrm{H})$, $2.77-2.63(\mathrm{~m}, 0.5 \mathrm{H}), 2.36-2.18(\mathrm{~m}, 1 \mathrm{H}), 2.13-2.01(\mathrm{~m}$, $0.5 \mathrm{H}) .{ }^{13} \mathrm{C}$ NMR $\left(100 \mathrm{MHz}, \mathrm{DMSO}-d_{6}\right): \delta 177.7,177.7$, $167.2,167.1,161.1,161.1,159.8,159.5,140.9,140.6$, $140.3,136.7,136.7,136.6,136.5,136.1,136.1,135.8$, 135.7, 133.8, 133.6, 132.0, 131.8, 131.5, 131.4, 130.4, 130.0, 124.4, 64.3, 63.5, 56.3, 56.3, 56.2, 55.3, 55.0, 31.7, 31.5. APSI MS: $463.8\left(\mathrm{M}^{+}+1\right)$. Anal. Calcd for $\mathrm{C}_{21} \mathrm{H}_{15} \mathrm{Cl}_{2} \mathrm{NO}_{5} \mathrm{~S}$ : C, 54.32; H, 3.26; Cl, 15.27; N, 3.02; S, 6.90\%. Found: C, 54.34; H, 3.29; Cl, 15.36; N, 3.13; S, 6.98\%.

2,7-Dimethyl-1-phenyl-1H-chromeno[2,3-c]pyrrole3,9-dione (4\{3-1-2\}) Yield: 76\%; mp 242-244 ${ }^{\circ} \mathrm{C}$; IR (KBr): 2921, 1710 ( $\mathrm{C}=\mathrm{O}), 1651(\mathrm{C}=\mathrm{O}), 1614,1477,1422,1386$, 1276, 1255, 1212, 1137, 1096, 835, $703 \mathrm{~cm}^{-1}$. ${ }^{1} \mathrm{H}$ NMR (500 MHz, CF $\mathrm{COOD}_{3} \delta 8.13(\mathrm{~s}, 1 \mathrm{H}), 7.84$ (br. d, $J=8.3 \mathrm{~Hz}$, $1 \mathrm{H}), 7.73(\mathrm{~d}, J=8.6 \mathrm{~Hz}, 1 \mathrm{H}), 7.53-7.41(\mathrm{~m}, 3 \mathrm{H}), 7.33(\mathrm{~d}$, $J=5.9 \mathrm{~Hz}, 2 \mathrm{H}), 5.73(\mathrm{~s}, 1 \mathrm{H}), 3.15(\mathrm{~s}, 3 \mathrm{H}), 2.56(\mathrm{~s}, 3 \mathrm{H}) .{ }^{13} \mathrm{C}$ NMR (125 MHz, $\left.\mathrm{CF}_{3} \mathrm{COOD}, \mathrm{APT}\right): 175.9$ (C), 163.4 (C), $155.3(\mathrm{C}), 155.0(\mathrm{C}), 138.3(\mathrm{C}), 137.4(\mathrm{CH}), 129.7(\mathrm{CH})$, $129.5(\mathrm{C}), 128.9(\mathrm{CH}), 126.9(\mathrm{CH}), 126.6(\mathrm{C}), 124.4(\mathrm{CH})$, $123.2(\mathrm{C}), 117.9(\mathrm{CH}), 63.8(\mathrm{CH}), 26.8\left(\mathrm{CH}_{3}\right), 18.8\left(\mathrm{CH}_{3}\right)$. 
APSI MS: $306\left(\mathrm{M}^{+}+1\right)$. Anal. Calcd for $\mathrm{C}_{19} \mathrm{H}_{17} \mathrm{NO}_{3}$ : C, 74.74; H, 4.95; N, 4.59\%. Found: C, 74.84; H, 5.03; N, $4.53 \%$.

2-Allyl-1-(4-ethylphenyl)-7-methyl-1,2dihydrochromeno[2,3-c]pyrrole-3,9-dione (4\{3-3-6\}) Yield: 43\%; mp 235-237 ${ }^{\circ} \mathrm{C}$; IR (KBr): 2965, 1709 (C=O), 1652 $(\mathrm{C}=\mathrm{O}), 1615,1477,1408,1279,1211,1138,836 \mathrm{~cm}^{-1}$. ${ }^{1} \mathrm{H}$ NMR $\left(400 \mathrm{MHz}\right.$, DMSO- $\left.d_{6}\right) \delta 7.81(\mathrm{~s}, 1 \mathrm{H}), 7.74-7.63$ $(\mathrm{m}, 2 \mathrm{H}), 7.20(\mathrm{~s}, 4 \mathrm{H}), 5.80-5.66(\mathrm{~m}, 1 \mathrm{H}), 5.57(\mathrm{~s}, 1 \mathrm{H})$, $5.16-5.03(\mathrm{~m}, 1 \mathrm{H}), 4.30(\mathrm{dd}, J=15.7,3.3 \mathrm{~Hz}, 1 \mathrm{H}), 3.41$ $(\mathrm{dd}, J=15.4,6.0 \mathrm{~Hz}, 1 \mathrm{H}), 2.61(\mathrm{q}, J=7.5 \mathrm{~Hz}, 2 \mathrm{H}), 2.42(\mathrm{~s}$, $3 \mathrm{H}), 1.18(\mathrm{t}, J=7.5 \mathrm{~Hz}, 3 \mathrm{H}) .{ }^{13} \mathrm{C}$ NMR $(100 \mathrm{MHz}$, DMSO$\left.d_{6}\right): \delta 173.0,161.4,154.9,154.6,144.7,136.3,132.9,131.4$, 128.6, 128.4, 127.6, 125.0, 124.9, 119.3, 118.2, 59.5, 43.0, $28.3,20.8,15.8$. APSI MS: $360.0\left(\mathrm{M}^{+}+1\right)$. Anal. Calcd for $\mathrm{C}_{23} \mathrm{H}_{21} \mathrm{NO}_{3}$ : C, 76.86; H, 5.89; N, 3.90\%. Found: C, 76.89; $\mathrm{H}, 5.86 ; \mathrm{N}, 3.96 \%$.

2-(2-Hydroxyethyl)-5,7-dimethyl-1-(3,4,5trimethoxyphenyl)-1,2-dihydrochromeno-[2,3-c]pyrrole3,9-dione (4\{4-19-7\}) Yield: 52\%; mp 195-197 ${ }^{\circ} \mathrm{C}$; IR (KBr): 3371, 2936, 1711, 1593, 1505, 1462, 1422, 1355, $1256,1231,1122,1073,1000,823,766,705,569 \mathrm{~cm}^{-1} .{ }^{1} \mathrm{H}$ NMR (400 MHz, DMSO- $\left.d_{6}\right) \delta 7.63(\mathrm{~s}, 1 \mathrm{H}), 7.55(\mathrm{~s}, 1 \mathrm{H})$, $6.67(\mathrm{~s}, 2 \mathrm{H}), 5.67(\mathrm{~s}, 1 \mathrm{H}), 4.86$ (br. s, 1H), 3.81-3.68 (m, $7 \mathrm{H}), 3.65(\mathrm{~s}, 3 \mathrm{H}), 3.57-3.44(\mathrm{~m}, 2 \mathrm{H}), 2.92-2.81(\mathrm{~m}, 1 \mathrm{H})$, $2.49(\mathrm{~s}, 3 \mathrm{H}), 2.37$ (s, 3H). ${ }^{13} \mathrm{C}$ NMR (100 MHz, DMSO- $\left.d_{6}\right)$ : $\delta 173.2,161.9,155.0,153.5,153.1,137.9,137.0,135.5$, 130.1, 128.3, 126.9, 125.0, 122.7, 105.8, 60.7, 60.4, 58.9, 56.5, 43.2, 20.8, 15.6. APSI MS: $440.1\left(\mathrm{M}^{+}+1\right)$. Anal. Calcd for $\mathrm{C}_{24} \mathrm{H}_{25} \mathrm{NO}_{7}$ : C, 65.59; H, 5.73; N, 3.19\%. Found: C, 65.56; H, 5.76; N, 3.27\%.

1-(4-(Allyloxy)-3-methoxyphenyl)-2-(2-methoxyethyl)6,7-dimethyl-1,2-dihydro-chromeno[2,3-c]pyrrole-3,9-dione (4\{5-17-9\}) Yield: 55\%; mp 166-169 ${ }^{\circ} \mathrm{C}$; IR (KBr): 2924, $1712(\mathrm{C}=\mathrm{O}), 1659(\mathrm{C}=\mathrm{O}), 1622,1517,1465,1426$, $1262,1230,1143,1013 \mathrm{~cm}^{-1}$. ${ }^{1} \mathrm{H}$ NMR (400 MHz, DMSO$\left.d_{6}\right) \delta 7.71$ (br. s, $\left.1 \mathrm{H}\right), 7.59$ (br. s, $\left.1 \mathrm{H}\right), 6.92(\mathrm{~d}, J=7.3 \mathrm{~Hz}$, 1H), $6.88(\mathrm{~s}, 1 \mathrm{H}), 6.09-5.95(\mathrm{~m}, 1 \mathrm{H}), 5.63(\mathrm{~s}, 1 \mathrm{H}), 5.38(\mathrm{~d}$, $J=16.9 \mathrm{~Hz}, 1 \mathrm{H}), 5.24(\mathrm{~d}, J=9.8 \mathrm{~Hz}, 1 \mathrm{H}), 4.54(\mathrm{~s}, 2 \mathrm{H}), 3.84$ (d, $J=13.5 \mathrm{~Hz}, 1 \mathrm{H}), 3.69$ (s, 3H), $3.40\left(\mathrm{~m}\right.$, in $\left.\mathrm{H}_{2} \mathrm{O}\right), 3.21$ (s), $2.91(\mathrm{~d}, J=14.0 \mathrm{~Hz}, 1 \mathrm{H}), 2.37(\mathrm{~s}, 3 \mathrm{H}), 2.29(\mathrm{~s}, 3 \mathrm{H}) .{ }^{13} \mathrm{C}$ NMR (100 MHz, DMSO- $\left.d_{6}\right): \delta 172.8,161.7,154.8,154.6$, $149.6,148.3,145.5,135.6,134.2,127.5,126.7,125.1$, 123.1, 121.1, 119.3, 118.0, 113.7, 111.8, 69.6, 69.3, 60.2, 58.4, 56.1, 20.3, 19.3. APSI MS: 450.2 $\left(\mathrm{M}^{+}+1\right)$. Anal. Calcd for $\mathrm{C}_{26} \mathrm{H}_{27} \mathrm{NO}_{6}$ : C, 69.47; H, 6.05; N, 3.12\%. Found: C, 69.45; H, 6.07; N, 3.25\%.

7-Fluoro-2-(4-methoxyphenethyl)-1-(3-propoxyphenyl)1,2-dihydrochromeno[2,3-c]pyrrole-3,9-dione (4\{7-7-25\}) Yield: 58\%; mp 170-172 ${ }^{\circ} \mathrm{C}$; IR (KBr): 2911, $1713(\mathrm{C}=\mathrm{O})$, $1656(\mathrm{C}=\mathrm{O}), 1620,1517,1477,1401,1252,1134 \mathrm{~cm}^{-1}$. ${ }^{1} \mathrm{H}$ NMR (400 MHz, DMSO- $\left.d_{6}\right) \delta 7.96(\mathrm{dd}, J=9.2,4.2 \mathrm{~Hz}$, 1H), 7.81-7.73 (m, 1H), $7.70(\mathrm{dd}, J=8.3,3.0 \mathrm{~Hz}, 1 \mathrm{H}), 7.27$ (t, $J=7.8 \mathrm{~Hz}, 1 \mathrm{H}), 7.06(\mathrm{~d}, J=8.5 \mathrm{~Hz}, 2 \mathrm{H}), 6.94-6.84(\mathrm{~m}$, $3 \mathrm{H}), 6.82(\mathrm{~d}, J=8.5 \mathrm{~Hz}, 2 \mathrm{H}), 5.54(\mathrm{~s}, 1 \mathrm{H}), 3.94-3.80(\mathrm{~m}$, $3 \mathrm{H}), 3.71(\mathrm{~s}, 3 \mathrm{H}), 3.03-2.90(\mathrm{~m}, 1 \mathrm{H}), 2.86-2.75(\mathrm{~m}, 1 \mathrm{H})$, $2.68-2.58(\mathrm{~m}, 1 \mathrm{H}), 1.71(\mathrm{dt}, J=13.9,6.9 \mathrm{~Hz}, 2 \mathrm{H}), 0.96(\mathrm{t}$, $J=7.4 \mathrm{~Hz}, 1 \mathrm{H}) .{ }^{13} \mathrm{C}$ NMR (100 MHz, DMSO- $\left.d_{6}\right): \delta 172.3$, $160.7,160.27$ (d, $J=213.6 \mathrm{~Hz}), 158.7,158.3,155.7,152.8$, 135.7, 130.7, 130.3, 130.01, $126.6(\mathrm{~d}, J=7.0 \mathrm{~Hz}), 126.5$, $123.2(\mathrm{~d}, J=23.6 \mathrm{~Hz}), 122.4(\mathrm{~d}, J=8.2 \mathrm{~Hz}), 120.4,115.1$, 114.6, 114.3, 110.5 (d, $J=20.9 \mathrm{~Hz}), 69.4,59.8,55.4,42.4$, 22.5, 10.8. APSI MS: $488.0\left(\mathrm{M}^{+}+1\right)$. Anal. Calcd for $\mathrm{C}_{29} \mathrm{H}_{26} \mathrm{FNO}_{5}$ : C, 71.45; $\mathrm{H}, 5.38 ; \mathrm{N}, 2.87 \%$. Found: $\mathrm{C}, 71.47$; $\mathrm{H}, 5.40 ; \mathrm{N}, 2.94 \%$.

7-Chloro-1-(4-hydroxyphenyl)-2-phenethyl-1,2dihydrochromeno[2,3-c]pyrrole-3,9-dione (4\{8-11-24\}) Yield: $72 \%$; $\mathrm{mp}>295{ }^{\circ} \mathrm{C}$; IR ( $\left.\mathrm{KBr}\right): 3386,1701(\mathrm{C}=\mathrm{O})$, $1647(\mathrm{C}=\mathrm{O}), 1605,1517,1451,1417,1253,1225,1171$, $1113,840,696 \mathrm{~cm}^{-1} .{ }^{1} \mathrm{H}$ NMR $\left(400 \mathrm{MHz}\right.$, DMSO- $\left.d_{6}\right) \delta 9.53$ (s, 1H), 7.95-7.89 (m, 3H), 7.27 (t, J=7.3 Hz, 2H), 7.20 (t, $J=6.8 \mathrm{~Hz}, 1 \mathrm{H}), 7.13(\mathrm{dd}, J=13.5,7.9 \mathrm{~Hz}, 4 \mathrm{H}), 6.75$ (d, $J=8.4 \mathrm{~Hz}, 2 \mathrm{H}), 5.46(\mathrm{~s}, 1 \mathrm{H}), 3.90-3.78(\mathrm{~m}, 1 \mathrm{H}), 3.03-2.92$ (m, 1H), 2.91-2.80 (m, 1H), 2.72-2.60 (m, 1H). ${ }^{13} \mathrm{C}$ NMR $\left(100 \mathrm{MHz}, \mathrm{DMSO}-d_{6}\right): \delta 171.9,160.9,158.3,155.4,155.0$, $138.8,135.1,131.0,129.7,129.0,128.9,127.5,126.9$, 126.5, 124.65, 123.7, 122.2, 116.0, 59.5, 42.0, 34.1. APSI MS: $432.0\left(\mathrm{M}^{+}+1\right)$. Anal. Calcd for $\mathrm{C}_{25} \mathrm{H}_{18} \mathrm{ClNO}_{4}$ : C, 69.53; H, 4.20; Cl, 8.21; N, 3.24\%. Found: C, 69.51; H, $4.23 ; \mathrm{Cl}, 8.29 ; \mathrm{N}, 3.28 \%$.

7-Chloro-2-(furan-2-ylmethyl)-1-(3-hydroxyphenyl)6-methyl-1,2-dihydrochromeno-[2,3-c]pyrrole-3,9-dione (4\{9-5-21\}) Yield: $62 \%$; mp $276-279{ }^{\circ} \mathrm{C}$; IR (KBr): 3330, 1694, 1659 (C=O), 1615, 1487, 1428, 1268, 1208, 1146, $691 \mathrm{~cm}^{-1} .{ }^{1} \mathrm{H}$ NMR (400 MHz, DMSO- $\left.d_{6}\right) \delta 9.51$ (br. s, 1H), $7.94(\mathrm{~s}, 1 \mathrm{H}), 7.90(\mathrm{~s}, 1 \mathrm{H}), 7.59(\mathrm{~s}, 1 \mathrm{H}), 7.16$ (t, $J=7.8 \mathrm{~Hz}, 1 \mathrm{H}), 6.74(\mathrm{~m}, 2 \mathrm{H}), 6.68(\mathrm{~m}, 1 \mathrm{H}), 6.39(\mathrm{dd}$, $J=3.0,1.9 \mathrm{~Hz}, 1 \mathrm{H}), 6.25(\mathrm{~d}, J=3.0 \mathrm{~Hz}, 1 \mathrm{H}), 5.38(\mathrm{~s}, 1 \mathrm{H})$, $4.92(\mathrm{~d}, J=15.9 \mathrm{~Hz}, 1 \mathrm{H}), 3.90(\mathrm{~d}, J=15.9 \mathrm{~Hz}, 1 \mathrm{H}), 2.48$ (s, 3H). ${ }^{13} \mathrm{C}$ NMR (100 MHz, DMSO- $\left.d_{6}\right): \delta 171.8,161.1$, $158.1,154.8,154.7,149.6,144.0,143.5,134.9,131.9$, $130.3,127.6,124.8,124.5,121.8,118.9,116.3,115.1$, 111.0, 109.2, 59.8, 37.1, 20.6. APSI MS: $422.0\left(\mathrm{M}^{+}+1\right)$. Anal. Calcd for $\mathrm{C}_{23} \mathrm{H}_{16} \mathrm{ClNO}_{5}$ : C, 65.49; $\mathrm{H}, 3.82 ; \mathrm{Cl}, 8.40$; N, 3.32\%. Found: C, $65.45 ; \mathrm{H}, 3.80 ; \mathrm{Cl}, 8.48 ; \mathrm{N}, 3.40 \%$.

\section{General procedure for the synthesis of 3-(2-hydroxyphenyl)-4,5-dihydropyrrolo-[3,4-c] pyrazol-6(1H)-ones 5}

Solution of $0.01 \mathrm{~mol}$ of chromeno[2,3-c]pyrrole-3,9-dione 4 and $0.05 \mathrm{~mol}$ of hydrazine hydrate in dry dioxane $(10 \mathrm{~mL})$ in a 20-mL glass vial was stirred at $80^{\circ} \mathrm{C}$ for $15-20 \mathrm{~h}$. After the completion of the reaction (reaction progress was monitored with TLC), the reaction mixture was allowed to cool down to 
rt, diluted with distil $\mathrm{H}_{2} \mathrm{O}(5 \mathrm{~mL})$; the precipitate was filtered off and recrystallized from ethanol $(5-7 \mathrm{~mL})$.

*The exact position of the $\mathrm{C}=\mathrm{O}$ and pyrazole signals cannot be established for certain compounds due to their low intensity.

3-(2-Hydroxyphenyl)- 5 - methyl-4-phenyl4,5-dihydropyrrolo[3,4-c]pyrazol-6(1H)-one (5\{1-1-2\}) Yield: $94 \%$; mp $>290{ }^{\circ} \mathrm{C}$; IR (KBr): 3261-2414 (OH, NH), $1674,1543,1454,1401,1248,826,744,695,636 \mathrm{~cm}^{-1}$. ${ }^{1} \mathrm{H}$ NMR (400 MHz, DMSO- $\left.d_{6}\right) \delta 7.33-7.20(\mathrm{~m}, 4 \mathrm{H})$, $7.16(\mathrm{~d}, J=7.1 \mathrm{~Hz}, 2 \mathrm{H}), 7.10(\mathrm{t}, J=7.7 \mathrm{~Hz}, 1 \mathrm{H}), 6.89$ (d, $J=8.1 \mathrm{~Hz}, 1 \mathrm{H}), 6.71(\mathrm{t}, J=7.4 \mathrm{~Hz}, 1 \mathrm{H}), 5.68(\mathrm{~s}, 1 \mathrm{H}), 2.73(\mathrm{~s}$, $3 \mathrm{H})$; $\mathrm{OH}$ and $\mathrm{NH}$ exchanged with $\mathrm{H}_{2} \mathrm{O} .{ }^{13} \mathrm{C}$ NMR $(100 \mathrm{MHz}$, DMSO- $\left.d_{6}\right): \delta 162.6,154.7,150.3,137.6,134.5,130.0$, 129.2, 128.8, 128.1, 126.7, 119.5, 116.6, 115.7, 62.2, 27.9. APSI MS: $306.2\left(\mathrm{M}^{+}+1\right)$. Anal. Calcd for $\mathrm{C}_{18} \mathrm{H}_{15} \mathrm{~N}_{3} \mathrm{O}_{2}$ : $\mathrm{C}$, $70.81 ; \mathrm{H}, 4.95 ; \mathrm{N}, 13.76 \%$. Found: C, 70.80; H, 4.92; N, $13.81 \%$.

3-(2-Hydroxyphenyl)-5-(3-isopropoxypropyl)-4-(p-tolyl)4,5-dihydropyrrolo[3,4-c]-pyrazol-6(1H)-one (5\{1-2-12\}) Yield: $75 \%$; mp $198-200{ }^{\circ} \mathrm{C}$; IR (KBr): 3468-2535 (OH, $\mathrm{NH}), 1678,1543,1464,1260,1129,1090,820,760,700$, $638 \mathrm{~cm}^{-1} .{ }^{1} \mathrm{H}$ NMR $\left(400 \mathrm{MHz}, \mathrm{DMSO}-d_{6}\right) \delta 13.35$ (br. s, $1 \mathrm{H}), 10.40$ (br. s, $1 \mathrm{H}), 7.25$ (d, $J=7.6 \mathrm{~Hz}, 1 \mathrm{H}), 7.13-7.01$ $(\mathrm{m}, 5 \mathrm{H}), 6.88(\mathrm{~d}, J=8.1 \mathrm{~Hz}, 1 \mathrm{H}), 6.71(\mathrm{t}, J=7.5 \mathrm{~Hz}, 1 \mathrm{H})$, $5.75(\mathrm{~s}, 1 \mathrm{H}), 3.65$ (dt, $J=14.4,7.4 \mathrm{~Hz}, 1 \mathrm{H}), 3.50-3.39$ (m, $1 \mathrm{H}), 3.30(\mathrm{t}, J=6.0 \mathrm{~Hz}, 2 \mathrm{H}), 2.73-2.66(\mathrm{~m}, 1 \mathrm{H}), 2.21(\mathrm{~s}$, $3 \mathrm{H}), 1.77-1.53(\mathrm{~m}, 2 \mathrm{H}), 1.02(\mathrm{dd}, J=5.9,3.0 \mathrm{~Hz}, 6 \mathrm{H}) .{ }^{13} \mathrm{C}$ NMR $\left(100 \mathrm{MHz}\right.$, DMSO- $\left.d_{6}\right): \delta 137.9,130.9,129.8,128.8$, 128.1, 119.5, 116.5, 71.0, 65.3, 60.1, 38.1, 28.8, 22.5, 21.2; *. APSI MS: $406.2\left(\mathrm{M}^{+}+1\right)$. Anal. Calcd for $\mathrm{C}_{24} \mathrm{H}_{27} \mathrm{~N}_{3} \mathrm{O}_{3}$ : C, 71.09; H, 6.71; N, 10.36\%. Found: C, 71.05; H, 6.73; N, $10.40 \%$.

3-(2-Hydroxyphenyl)-4-(3-(pentyloxy)phenyl)-5-propyl4,5-dihydropyrrolo[3,4-c]-pyrazol-6(1H)-one (5\{1-8-4\}) Yield: 83\%; mp 242-244 ${ }^{\circ} \mathrm{C}$; IR (KBr): 3339-2720 (OH, $\mathrm{NH}), 1689,1583,1533,1462,1427,1284,1231,1091,1011$, $965,818,741,700,639 \mathrm{~cm}^{-1}$. ${ }^{1} \mathrm{H}$ NMR (400 MHz, DMSO$d_{6}$ ) $\delta 13.40$ (br. s, $\left.1 \mathrm{H}\right), 10.40$ (br. s, $\left.1 \mathrm{H}\right), 7.26(\mathrm{~d}, J=7.7 \mathrm{~Hz}$, $1 \mathrm{H}), 7.18(\mathrm{t}, J=7.9 \mathrm{~Hz}, 1 \mathrm{H}), 7.11(\mathrm{t}, J=7.7 \mathrm{~Hz}, 1 \mathrm{H}), 6.89$ (d, $J=8.1 \mathrm{~Hz}, 1 \mathrm{H}), 6.79(\mathrm{~d}, J=7.7 \mathrm{~Hz}, 1 \mathrm{H}), 6.76-6.67(\mathrm{~m}$, $3 \mathrm{H}), 5.74(\mathrm{~s}, 1 \mathrm{H}), 3.91-3.77(\mathrm{~m}, 2 \mathrm{H}), 3.63-3.50(\mathrm{~m}, 1 \mathrm{H})$, 2.71-2.59 (m, 1H), 1.69-1.58 (m, 2H), 1.56-1.46 (m, 1H), $1.46-1.37(\mathrm{~m}, 1 \mathrm{H}), 1.37-1.24(\mathrm{~m}, 4 \mathrm{H}), 0.86(\mathrm{t}, J=6.9 \mathrm{~Hz}$, $3 \mathrm{H}), 0.79(\mathrm{t}, J=7.3 \mathrm{~Hz}, 3 \mathrm{H}) .{ }^{13} \mathrm{C}$ NMR $(100 \mathrm{MHz}$, DMSO$\left.d_{6}\right)^{*}: \delta 162.8,159.2,154.5,130.3,130.0,128.9,126.6$, 119.8, 119.4, 116.4, 114.4, 114.3, 67.8, 59.9, 42.2, 28.7, 28.1, 22.3, 21.5, 14.3, 11.7. APSI MS: $420.2\left(\mathrm{M}^{+}+1\right)$. Anal. Calcd for $\mathrm{C}_{25} \mathrm{H}_{29} \mathrm{~N}_{3} \mathrm{O}_{3}: \mathrm{C}, 71.57 ; \mathrm{H}, 6.97 ; \mathrm{N}, 10.02 \%$. Found: C, $71.55 ; \mathrm{H}, 6.96 ; \mathrm{N}, 10.13 \%$.

5-(Benzo[d][1,3]dioxol-5-ylmethyl)-3-(2-hydroxyphenyl)4-(4-hydroxyphenyl)-4,5-dihydropyrrolo[3,4-c]pyrazol$6(1 H)$-one (5\{1-11-18\}) Yield: $90 \%$; mp $280-282{ }^{\circ} \mathrm{C}$; IR
(KBr): 3532-2545 (OH, NH), 1664, 1600, 1515, 1473, 1337, 1246, 1209, 1086, 1039, 1000, 926, 841, 804, 740, $670,564 \mathrm{~cm}^{-1}$. ${ }^{1} \mathrm{H}$ NMR (400 MHz, DMSO- $d_{6}$ ) $\delta 13.44$ (br. s, $1 \mathrm{H}$ ), 10.32 (br. s, 1H), 9.47 (br. s, $1 \mathrm{H}$ ), 7.22 (d, $J=7.6 \mathrm{~Hz}, 1 \mathrm{H}), 7.10-7.06(\mathrm{~m}, 1 \mathrm{H}), 6.87-6.83(\mathrm{~m}, 4 \mathrm{H})$, 6.69-6.62 (m, 5H), $5.99(\mathrm{~d}, J=6.0 \mathrm{~Hz}, 2 \mathrm{H}), 5.42(\mathrm{~s}, 1 \mathrm{H})$, $4.86(\mathrm{~d}, J=15.2 \mathrm{~Hz}, 1 \mathrm{H}), 3.54(\mathrm{~d}, J=15.6 \mathrm{~Hz}, 1 \mathrm{H}) .{ }^{13} \mathrm{C}$ NMR (100 MHz, DMSO- $\left.d_{6}\right) *: \delta 157.7,147.9,146.8,131.8$, 130.0, 129.4, 128.8, 121.4, 119.5, 116.4, 115.9, 108.7, 108.5, 101.4, 59.5, 43.6. APSI MS: 442,2 $\left(\mathrm{M}^{+}+1\right)$. Anal. Calcd for $\mathrm{C}_{25} \mathrm{H}_{19} \mathrm{~N}_{3} \mathrm{O}_{5}: \mathrm{C}, 68.02 ; \mathrm{H}, 4.34 ; \mathrm{N}, 9.52 \%$. Found: C, 68.00; H, 4.36; N, 9.60\%.

4-(4-(Benzyloxy)phenyl)-3-(2-hydroxyphenyl)-5-(3methoxypropyl)-4,5-dihydro-pyrrolo[3,4-c]pyrazol-6(1H)one (5\{1-15-10\}) Yield: $72 \%$; mp $173-175{ }^{\circ} \mathrm{C}$; IR (KBr): 3296-2621 (OH, NH), 1668, 1515, 1462, 1250, 1109, 744, $691,636 \mathrm{~cm}^{-1}$. ${ }^{1} \mathrm{H}$ NMR (400 MHz, DMSO- $\left.d_{6}\right) \delta 13.40$ (br. s, 1H), 10.40 (br. s, 1H), 7.46-7.28 (m, 5H), 7.23 (d, $J=7.5 \mathrm{~Hz}, 1 \mathrm{H}), 7.16-7.06(\mathrm{~m}, 3 \mathrm{H}), 6.94(\mathrm{~d}, J=8.5 \mathrm{~Hz}$, $2 \mathrm{H}), 6.89(\mathrm{~d}, J=8.1 \mathrm{~Hz}, 1 \mathrm{H}), 6.71(\mathrm{t}, J=7.3 \mathrm{~Hz}, 1 \mathrm{H})$, $5.74(\mathrm{~s}, 1 \mathrm{H}), 5.01(\mathrm{~s}, 2 \mathrm{H}), 3.68-3.55(\mathrm{~m}, 1 \mathrm{H}), 3.31-3.23$ $(\mathrm{m}, 2 \mathrm{H}), 3.18(\mathrm{~s}, 3 \mathrm{H}), 2.79-2.66(\mathrm{~m}, 1 \mathrm{H}), 1.80-1.67(\mathrm{~m}$, 1H), $1.67-1.54(\mathrm{~m}, 1 \mathrm{H}) .{ }^{13} \mathrm{C}$ NMR (100 MHz, DMSO- $\left.d_{6}\right)^{*}$ : $\delta 158.7,137.3,130.0,129.5,128.9,128.3,119.5,116.5$, 115.4, 70.0, 69.7, 59.9, 58.3, 38.0, 28.4. APSI MS: 470.2 $\left(\mathrm{M}^{+}+1\right)$. Anal. Calcd for $\mathrm{C}_{28} \mathrm{H}_{27} \mathrm{~N}_{3} \mathrm{O}_{4}: \mathrm{C}, 71.62 ; \mathrm{H}, 5.80$; $\mathrm{N}, 8.95 \%$. Found: C, 71.63; H, 5.83; N, 8.99\%.

4-(4-Hydroxy-3-methoxyphenyl)-3-(2-hydroxyphenyl)5-propyl-4,5-dihydropyrrolo-[3,4-c]pyrazol-6(1H)-one (5\{1-16-4\}) Yield: 78\%; mp 243-245 ${ }^{\circ} \mathrm{C}$; IR (KBr): 3496-2797 (OH, NH), 1677, 1600, 1515, 1467, 1391, 1258, 1220, 1128, 1183, 1037, 741, $718 \mathrm{~cm}^{-1} .{ }^{1} \mathrm{H}$ NMR $\left(400 \mathrm{MHz}, \mathrm{DMSO}-d_{6}\right) \delta 7.17(\mathrm{~d}, J=7.7 \mathrm{~Hz}, 1 \mathrm{H}), 7.05(\mathrm{t}$, $J=7.7 \mathrm{~Hz}, 1 \mathrm{H}), 6.88(\mathrm{~d}, J=8.1 \mathrm{~Hz}, 1 \mathrm{H}), 6.76(\mathrm{~s}, 1 \mathrm{H}), 6.70$ $(\mathrm{d}, J=8.1 \mathrm{~Hz}, 1 \mathrm{H}), 6.62(\mathrm{~m}, 2 \mathrm{H}), 5.65(\mathrm{~s}, 1 \mathrm{H}), 3.64(\mathrm{~s}, 3 \mathrm{H})$, 3.61-3.49 (m, 1H), 2.76-2.64 (m, 1H), 1.57-1.33 (m, 2H), $0.79(\mathrm{t}, \mathrm{J}=7.3 \mathrm{~Hz}, 3 \mathrm{H}) ; \mathrm{OH}$ and $\mathrm{NH}$ exchanged with $\mathrm{H}_{2} \mathrm{O}$. ${ }^{13} \mathrm{C}$ NMR (100 MHz, DMSO- $\left.d_{6}\right): \delta 162.3,156.4,149.0$, 148.1, 146.9, 137.5, 129.4, 128.6, 128.2, 127.0, 120.6, 118.5, $116.8,116.3,116.1,112.2,59.9,56.1,42.1,21.6,11.7$. APSI MS: $380.2\left(\mathrm{M}^{+}+1\right)$. Anal. Calcd for $\mathrm{C}_{21} \mathrm{H}_{21} \mathrm{~N}_{3} \mathrm{O}_{4}$ : C, 66.48; $\mathrm{H}, 5.58 ; \mathrm{N}, 11.08 \%$. Found: C, 66.50; H, 5.55; N, $11.12 \%$.

3-(2-Hydroxyphenyl)-5-(pyridin-4-ylmethyl)-4-(3,4,5trimethoxyphenyl)-4,5-dihydropyrrolo[3,4-c]pyrazol-6(1H)one (5\{1-19-23\}) Yield: $81 \%$; mp 280-282 ${ }^{\circ} \mathrm{C}$; IR (KBr): $3451(\mathrm{OH}), 2940,1689(\mathrm{C}=\mathrm{O}), 1658(\mathrm{C}=\mathrm{O}), 1596,1467$, $1425,1263,1249,1201,1129,1006,712 \mathrm{~cm}^{-1} .{ }^{1} \mathrm{H}$ NMR $\left(400 \mathrm{MHz}, \mathrm{DMSO}-d_{6}\right) \delta 8.45(\mathrm{~d}, J=5.9 \mathrm{~Hz}, 2 \mathrm{H}), 7.30(\mathrm{dd}$, $J=7.7,1.5 \mathrm{~Hz}, 1 \mathrm{H}), 7.17-7.08(\mathrm{~m}, 3 \mathrm{H}), 6.87(\mathrm{~d}, J=8.1 \mathrm{~Hz}$, $1 \mathrm{H}), 6.74(\mathrm{t}, J=7.6 \mathrm{~Hz}, 1 \mathrm{H}), 6.38(\mathrm{~s}, 2 \mathrm{H}), 5.62(\mathrm{~s}, 1 \mathrm{H})$, $4.85(\mathrm{~d}, J=16.4 \mathrm{~Hz}, 1 \mathrm{H}), 4.15(\mathrm{~d}, J=16.4 \mathrm{~Hz}, 1 \mathrm{H}), 3.59$ (s, 6H), 3.55 (s, 3H); $\mathrm{OH}$ and $\mathrm{NH}$ exchanged with $\mathrm{H}_{2} \mathrm{O}$. ${ }^{13} \mathrm{C}$ NMR $\left(100 \mathrm{MHz}, \mathrm{DMSO}-d_{6}\right) *: \delta 154.7,153.4,150.1$, 
147.1, 137.5, 130.2, 129.1, 122.9, 119.5, 116.3, 105.2, 61.1, 60.3, 56.2, 43.9. APSI MS: $473.0\left(\mathrm{M}^{+}+1\right)$. Anal. Calcd for $\mathrm{C}_{26} \mathrm{H}_{24} \mathrm{~N}_{4} \mathrm{O}_{5}: \mathrm{C}, 66.09 ; \mathrm{H}, 5.12 ; \mathrm{N}, 11.86 \%$. Found: $\mathrm{C}, 66.06$; $\mathrm{H}, 5.10 ; \mathrm{N}, 11.92 \%$.

4-(4-Chlorophenyl)-5-(1,1-dioxidotetrahydrothiophen3-yl)-3-(2-hydroxyphenyl)-4,5-dihydropyrrolo[3,4-c]pyrazol-6(1H)-one (5\{1-22-27\}) Yield: 75\%; mp 240-242 ${ }^{\circ} \mathrm{C}$; IR (KBr): 3471-2631 (OH, NH), 1671, 1624, 1587, 1544, 1491, 1462, 1412, 1317, 1239, 1127, 1093, 833, 741, 683, 570, $521 \mathrm{~cm}^{-1}$. Two diastereomers. ${ }^{1} \mathrm{H}$ NMR $(400 \mathrm{MHz}$, DMSO$\left.d_{6}\right) \delta 13.57$ (br. s, $\left.1 \mathrm{H}\right), 10.38$ (br. s, $\left.1 \mathrm{H}\right), 7.37-7.31(\mathrm{~m}, 2 \mathrm{H})$, $7.31-7.21(\mathrm{~m}, 3 \mathrm{H}), 7.12(\mathrm{t}, J=7.5 \mathrm{~Hz}, 1 \mathrm{H}), 6.89(\mathrm{dd}, J=7.9$, $3.4 \mathrm{~Hz}, 1 \mathrm{H}), 6.75(\mathrm{td}, J=7.5 \mathrm{~Hz}, 3.2 \mathrm{~Hz}, 1 \mathrm{H}), 5.96(\mathrm{~s}, 0.5 \mathrm{H})$, $5.92(\mathrm{~s}, 0.5 \mathrm{H}), 4.37-4.25(\mathrm{~m}, 0.5 \mathrm{H}), 4.25-4.16(\mathrm{~m}, 0.5 \mathrm{H})$, $3.63-3.52(\mathrm{~m}, 0.5 \mathrm{H}), 3.41(\mathrm{dd}, J=12.7,8.1 \mathrm{~Hz}, 0.5 \mathrm{H})$, $3.34-3.23(\mathrm{~m}, 1.5 \mathrm{H}), 3.13-3.00(\mathrm{~m}, 1 \mathrm{H}), 2.89(\mathrm{dd}, J=12.8$, $8.1 \mathrm{~Hz}, 0.5 \mathrm{H}), 2.69-2.53(\mathrm{~m}, 0.5 \mathrm{H}), 2.35(\mathrm{td}, J=10.6$, $7.8 \mathrm{~Hz}, 0.5 \mathrm{H}), 2.29-2.19(\mathrm{~m}, 0.5 \mathrm{H}), 1.97-1.86(\mathrm{~m}, 0.5 \mathrm{H})$. ${ }^{13} \mathrm{C}$ NMR (100 MHz, DMSO- $\left.d_{6}\right) *: \delta 154.6,133.3,133.2$, $130.3,130.1,129.2,128.7,128.5,119.5,116.4,61.0,60.4$, 51.8, 51.7, 51.7, 51.2, 50.7, 50.5, 26.9. APSI MS: 444.0 $\left(\mathrm{M}^{+}+1\right)$. Anal. Calcd for $\mathrm{C}_{21} \mathrm{H}_{18} \mathrm{ClN}_{3} \mathrm{O}_{4} \mathrm{~S}: \mathrm{C}, 56.82 ; \mathrm{H}$, 4.09; Cl, 7.99; N, 9.47; S, 7.22\%. Found: C, 56.80; H, 4.05; $\mathrm{Cl}, 7.90 ; \mathrm{N}, 9.57 ; \mathrm{S}, 7.28 \%$.

5-(Furan-2-ylmethyl)-3-(2-hydroxyphenyl)-4-(4(methylthio)phenyl)-4,5-dihydro-pyrrolo[3,4-c]pyrazol6(1H)-one (5\{1-25-21\}) Yield: $73 \%$; mp $242-244{ }^{\circ} \mathrm{C}$; IR (KBr): 3339-2720 (OH, NH), 1689, 1619, 1583, 1533, 1494, 1462, 1427, 1372, 1231, 1091, 833, 818, 742, $700 \mathrm{~cm}^{-1}$. ${ }^{1} \mathrm{H}$ NMR (400 MHz, DMSO- $d_{6}$ ) $\delta 13.50$ (br. s, $\left.1 \mathrm{H}\right), 10.50$ (br. s, $1 \mathrm{H}), 7.60(\mathrm{~s}, 1 \mathrm{H}), 7.30(\mathrm{~d}, J=7.7 \mathrm{~Hz}, 1 \mathrm{H}), 7.15$ (d, $J=8.1 \mathrm{~Hz}, 2 \mathrm{H}), 7.10(\mathrm{t}, J=7.3 \mathrm{~Hz}, 1 \mathrm{H}), 7.04(\mathrm{~d}, J=7.9 \mathrm{~Hz}$, $2 \mathrm{H}), 6.84(\mathrm{~d}, J=8.1 \mathrm{~Hz}, 1 \mathrm{H}), 6.73(\mathrm{t}, J=7.3 \mathrm{~Hz}, 1 \mathrm{H}), 6.41$ $(\mathrm{s}, 1 \mathrm{H}), 6.24(\mathrm{~d}, J=2.5 \mathrm{~Hz}, 1 \mathrm{H}), 5.53(\mathrm{~s}, 1 \mathrm{H}), 4.94(\mathrm{~d}$, $J=16.0 \mathrm{~Hz}, 1 \mathrm{H}), 3.67(\mathrm{~d}, J=16.0 \mathrm{~Hz}, 1 \mathrm{H}), 2.41(\mathrm{~s}, 3 \mathrm{H}) .{ }^{13} \mathrm{C}$ NMR $\left(100 \mathrm{MHz}, \text { DMSO- } d_{6}\right)^{*}: \delta 154.8,150.9,143.3,138.7$, 130.2, 128.8, 128.7, 126.3, 119.6, 116.4, 111.0, 108.7, 60.0, 36.9, 14.7. APSI MS: $418.2\left(\mathrm{M}^{+}+1\right)$. Anal. Calcd for $\mathrm{C}_{23} \mathrm{H}_{19} \mathrm{~N}_{3} \mathrm{O}_{3} \mathrm{~S}$ : C, 66.17; H, 4.59; N, 10.07; S, 7.68\%. Found: C, 66.15; H, 4.56; N, 10.17; S, 7.78\%.

3-(2-Hydroxy-5-methylphenyl)-5-methyl-4-phenyl-1,4dihydropyrrolo[3,4-c]pyrazol-6-one (5\{3-1-2\}) Yield: 85\%; mp 275-278 ${ }^{\circ} \mathrm{C}$; IR (KBr): 3619-2817 (OH, NH), 1649, 1487, 1458, 1383, 1264, 1085, 805, $710 \mathrm{~cm}^{-1}$. ${ }^{1} \mathrm{H}$ NMR $\left(400 \mathrm{MHz}, \mathrm{DMSO}-d_{6}\right) \delta 7.35(\mathrm{t}, J=7.4 \mathrm{~Hz}, 2 \mathrm{H}), 7.30(\mathrm{t}$, $J=7.0 \mathrm{~Hz}, 2 \mathrm{H}), 7.22(\mathrm{~d}, J=7.2 \mathrm{~Hz}, 2 \mathrm{H}), 6.96$ (br. s, $1 \mathrm{H}$ ), 6.92 (br. d, $J=8.2 \mathrm{~Hz}, 1 \mathrm{H}), 6.80(\mathrm{~d}, J=8.2 \mathrm{~Hz}, 1 \mathrm{H}), 5.70$ (s, $1 \mathrm{H}), 2.76(\mathrm{~s}, 3 \mathrm{H}), 2.08$ (s, 3H), $\mathrm{OH}$ and $\mathrm{NH}$ exchanged with $\mathrm{H}_{2} \mathrm{O} .{ }^{1} \mathrm{H}$ NMR (400 MHz, $\left.\mathrm{CF}_{3} \mathrm{COOD}\right) \delta 8.84$ (br. s, $1 \mathrm{H}$ ), $8.67-8.66(\mathrm{~m}, 1 \mathrm{H}), 8.52-8.50(\mathrm{~m}, 1 \mathrm{H}), 8.30-8.24(\mathrm{~m}, 2 \mathrm{H})$, $7.21(\mathrm{~s}, 1 \mathrm{H}), 4.43(\mathrm{~s}, 3 \mathrm{H}), 3.37$ (s, 3H). ${ }^{13} \mathrm{C}$ NMR $(100 \mathrm{MHz}$, DMSO- $d_{6}$, APT $)^{*}: 162.3(\mathrm{C}), 152.5(\mathrm{C}), 137.7$ (C), 130.4 $(\mathrm{CH}), 129.2(\mathrm{CH}), 129.1(\mathrm{CH}), 128.7(\mathrm{CH}), 128.2(\mathrm{CH})$,
$128.0(\mathrm{C}), 116.3(\mathrm{CH}), 115.3(\mathrm{C}), 62.1(\mathrm{CH}), 27.9\left(\mathrm{CH}_{3}\right)$, $20.3\left(\mathrm{CH}_{3}\right) \cdot{ }^{13} \mathrm{C}$ NMR $\left(100 \mathrm{MHz}, \mathrm{CF}_{3} \mathrm{COOD}\right): \delta 159.4$, $153.4,144.2,142.9,136.5,133.4,132.1,131.3,131.2$, 131.1, 129.1, 129.0, 117.6, 110.2, 66.2, 29.2, 19.2. APSI MS: $320.4\left(\mathrm{M}^{+}+1\right)$. Anal. Calcd for $\mathrm{C}_{19} \mathrm{H}_{17} \mathrm{~N}_{3} \mathrm{O}_{2}$ : C, 71.5; $\mathrm{H}, 5.4 ; \mathrm{N}, 13.2 \%$. Found: $\mathrm{C}, 71.3 ; \mathrm{H}, 5.6 ; \mathrm{N}, 13.4 \%$.

3-(2-Hydroxy-5-methylphenyl)-4-(3-hydroxyphenyl)-5-(3isopropoxypropyl)-4,5-dihydropyrrolo[3,4-c]pyrazol-6(1H)one (5\{3-5-12\}) Yield: $78 \%$; mp 232-235 ${ }^{\circ} \mathrm{C}$; IR (KBr): 3517-2484 (OH, NH), 1686, 1604, 1499, 1458, 1375, 1257, $1223,1038,1093,826,758,686 \mathrm{~cm}^{-1} .{ }^{1} \mathrm{H}$ NMR $(400 \mathrm{MHz}$, DMSO- $d_{6}$ ) $\delta 13.27$ (br. s, $1 \mathrm{H}$ ), 10.21 (br. s, $1 \mathrm{H}$ ), 9.40 (br. s, 1H), $7.13(\mathrm{t}, J=7.5 \mathrm{~Hz}, 1 \mathrm{H}), 6.96(\mathrm{~s}, 1 \mathrm{H}), 6.90(\mathrm{~d}$, $J=8.3 \mathrm{~Hz}, 1 \mathrm{H}), 6.83-6.71(\mathrm{~m}, 2 \mathrm{H}), 6.66(\mathrm{~d}, J=7.6 \mathrm{~Hz}, 1 \mathrm{H})$, $6.50(\mathrm{~s}, 1 \mathrm{H}), 5.71(\mathrm{~s}, 1 \mathrm{H}), 3.74-3.60(\mathrm{~m}, 1 \mathrm{H}), 3.50-3.41(\mathrm{~m}$, $1 \mathrm{H}), 3.34-3.24(\mathrm{~m}, 2 \mathrm{H}), 2.79-2.67(\mathrm{~m}, 1 \mathrm{H}), 2.07(\mathrm{~s}, 3 \mathrm{H})$, 1.79-1.57 (m, 2H), 1.11-0.98 (m, 6H). ${ }^{13} \mathrm{C}$ NMR $(100 \mathrm{MHz}$, DMSO- $\left.d_{6}\right) *: \delta 158.1,130.3,130.1,129.3,128.0,119.3$, 116.2, 115.8, 114.3, 71.0, 65.3, 60.0, 38.2, 28.8, 22.4, 20.2. APSI MS: $422.2\left(\mathrm{M}^{+}+1\right)$. Anal. Calcd for $\mathrm{C}_{24} \mathrm{H}_{27} \mathrm{~N}_{3} \mathrm{O}_{4}$ : C, 68.39; H, 6.46; N, 9.97\%. Found: C, 68.36; H, 6.54; N, $9.90 \%$.

4-(3-(Allyloxy)phenyl)-3-(2-hydroxy-5-methylphenyl)-5(2-hydroxyethyl)-4,5-dihydropyrrolo[3,4-c]pyrazol-6(1H)one (5\{3-9-7\}) Yield: 72\%; mp 229-231 ${ }^{\circ} \mathrm{C}$; IR (KBr): 3431-2627 (OH, NH), 1663, 1583, 1489, 1460, 1274, 1079, 1041, 806, $766 \mathrm{~cm}^{-1}$. ${ }^{1} \mathrm{H}$ NMR (400 MHz, DMSO$\left.d_{6}\right) \delta 13.32$ (br. s, $1 \mathrm{H}$ ), 10.19 (br. s, $\left.1 \mathrm{H}\right), 7.21$ (t, $J=8.0 \mathrm{~Hz}$, $1 \mathrm{H}), 6.99(\mathrm{~s}, 1 \mathrm{H}), 6.91(\mathrm{~d}, J=8.0 \mathrm{~Hz}, 1 \mathrm{H}), 6.88-6.75(\mathrm{~m}$, $3 \mathrm{H}$ ), 6.71 (br. d, $J=6.0 \mathrm{~Hz}, 1 \mathrm{H}$ ), 5.98 (ddd, $J=22.3,10.5$, $5.3 \mathrm{~Hz}, 1 \mathrm{H}), 5.84(\mathrm{~s}, 1 \mathrm{H}), 5.33(\mathrm{~d}, J=17.3 \mathrm{~Hz}, 1 \mathrm{H}), 5.21$ (d, $J=10.7 \mathrm{~Hz}, 1 \mathrm{H}), 4.82$ (br. t, $J=4.6 \mathrm{~Hz}, 1 \mathrm{H}$ ), 4.54-4.39 (m, 2H), 3.78-3.66 (m, 1H), 3.53 (td, $J=10.8,5.2 \mathrm{~Hz}, 1 \mathrm{H})$, 3.44 (td, $J=10.8,5.6 \mathrm{~Hz}, 1 \mathrm{H}), 2.76-2.63(\mathrm{~m}, 1 \mathrm{H}), 2.08(\mathrm{~s}$, $3 \mathrm{H}) .{ }^{13} \mathrm{C}$ NMR $\left(100 \mathrm{MHz}, \mathrm{DMSO}-d_{6}\right) *: \delta 158.7,152.4$, $133.9,130.4,130.3,129.2,127.9,120.2,117.9,116.2$, 115.0, 114.5, 68.6, 60.8, 59.4, 43.2, 20.2. APSI MS: 406.0 $\left(\mathrm{M}^{+}+1\right)$. Anal. Calcd for $\mathrm{C}_{23} \mathrm{H}_{23} \mathrm{~N}_{3} \mathrm{O}_{4}: \mathrm{C}, 68.13 ; \mathrm{H}, 5.72 ; \mathrm{N}$, $10.36 \%$. Found: C, 68.15; H, 5.75; N, $10.31 \%$.

3-(2-Hydroxy-3,5-dimethylphenyl)-5-(2-hydroxyethyl)-4(4-methoxyphenyl)-4,5-dihydropyrrolo[3,4-c]pyrazol-6(1H)one (5\{4-12-7\}) Yield: $81 \%$; mp 192-194 ${ }^{\circ} \mathrm{C}$; IR (KBr): 3428-2749 (OH, NH), 1661, 1511, 1483, 1391, 1241, 1174, 1063, 831, 784, 744, $696 \mathrm{~cm}^{-1}$. ${ }^{1} \mathrm{H}$ NMR $(400 \mathrm{MHz}$, DMSO- $d_{6}$ ) $\delta 14.20$ (br. s, $1 \mathrm{H}$ ), 10.65 (br. s, $1 \mathrm{H}$ ), 7.20 (br. d, $J=6.4 \mathrm{~Hz}, 2 \mathrm{H}), 6.90(\mathrm{~d}, J=8.1 \mathrm{~Hz}, 2 \mathrm{H}), 6.80(\mathrm{~s}, 1 \mathrm{H}), 6.74$ (s, 1H), 5.89 (s, 1H), 4.83 (br. s, 1H), 3.78-3.60 (m, 4H), 3.60-3.49 (m, 1H), 3.49-3.39 (m, 1H), 2.74-2.62 (m, 1H), $2.13(\mathrm{~s}, 3 \mathrm{H}), 2.02$ (s, 3H). ${ }^{13} \mathrm{C}$ NMR (100 MHz, DMSO$\left.d_{6}\right)^{*}: \delta 159.8,131.6,129.9,126.7,114.7,60.2,59.4,55.6$, 43.2, 20.2, 16.5. APSI MS: $394.0\left(\mathrm{M}^{+}+1\right)$. Anal. Calcd for $\mathrm{C}_{22} \mathrm{H}_{23} \mathrm{~N}_{3} \mathrm{O}_{4}$ : C, 67.16; H, 5.89; $\mathrm{N}, 10.68 \%$. Found: $\mathrm{C}, 67.14$; $\mathrm{H}, 5.86 ; \mathrm{N}, 10.73 \%$. 
5-(2-Chlorobenzyl)-4-(3-ethoxy-4-hydroxyphenyl)-3-(2hydroxy-3,5-dimethyl-phenyl)-4,5-dihydropyrrolo[3,4-c] pyrazol-6(1H)-one (5\{4-18-20\}) Yield: 84\%; mp 247-249 ${ }^{\circ} \mathrm{C}$; IR (KBr): 3571-2597 (OH, NH), 1689, 1610, $1515,1443,1276,1237,1210,1120,1039,825,750$, $617 \mathrm{~cm}^{-1} .{ }^{1} \mathrm{H}$ NMR (400 MHz, DMSO-d 6$) \delta 7.47-7.39(\mathrm{~m}$, $1 \mathrm{H}), 7.35-7.24$ (m, 2H), 7.18 (dd, $J=5.4,3.9 \mathrm{~Hz}, 1 \mathrm{H}), 6.80$ $(\mathrm{d}, J=3.9 \mathrm{~Hz}, 2 \mathrm{H}), 6.74(\mathrm{~s}, 1 \mathrm{H}), 6.69(\mathrm{~d}, J=8.1 \mathrm{~Hz}, 1 \mathrm{H})$, $6.54(\mathrm{~d}, J=7.4 \mathrm{~Hz}, 1 \mathrm{H}), 5.58(\mathrm{~s}, 1 \mathrm{H}), 4.91(\mathrm{~d}, J=16.3 \mathrm{~Hz}$, $1 \mathrm{H}), 4.01(\mathrm{~d}, J=16.2 \mathrm{~Hz}, 1 \mathrm{H}), 3.86(\mathrm{q}, J=6.9 \mathrm{~Hz}, 2 \mathrm{H}), 2.12$ $(\mathrm{s}, 3 \mathrm{H}), 2.00(\mathrm{~s}, 3 \mathrm{H}), 1.24(\mathrm{t}, J=6.9 \mathrm{~Hz}, 3 \mathrm{H}), \mathrm{OH}$ and $\mathrm{NH}$ exchanged with $\mathrm{H}_{2} \mathrm{O} .{ }^{13} \mathrm{C}$ NMR (100 MHz, DMSO- $\left.d_{6}\right) *$ : $\delta 154.5,151.0,147.4,147.1,134.8,132.5,131.7,129.8$, 129.5, 127.8, 126.9, 125.2, 120.8, 116.2, 115.6, 114.0, 64.3, 60.4, 42.1, 20.2, 16.6, 15.0. APSI MS: $504.0\left(\mathrm{M}^{+}+1\right)$. Anal. Calcd for $\mathrm{C}_{28} \mathrm{H}_{26} \mathrm{ClN}_{3} \mathrm{O}_{4}: \mathrm{C}, 66.73 ; \mathrm{H}, 5.20 ; \mathrm{Cl}, 7.03 ; \mathrm{N}$, 8.34\%. Found: C, 66.71; H, 5.23; Cl, 7.13; N, 8.41\%.

4-(4-Bromophenyl)-3-(2-hydroxy-3,5-dimethylphenyl)5-(pyridin-3-ylmethyl)-4,5-dihydropyrrolo [3,4-c]pyrazol6(1H)-one (5\{4-23-22\}) Yield: 81\%; mp 241-244 ${ }^{\circ} \mathrm{C}$; IR (KBr): 3367-2426 (OH, NH), 1699, 1559, 1481, 1435, 1253, 1072, 1011, 835, 751, 712, $636 \mathrm{~cm}^{-1} .{ }^{1} \mathrm{H}$ NMR (400 MHz, DMSO- $\left.d_{6}\right) \delta 8.47(\mathrm{~d}, J=4.3 \mathrm{~Hz}, 1 \mathrm{H}), 8.36(\mathrm{~s}, 1 \mathrm{H}), 7.58(\mathrm{~d}$, $J=7.7 \mathrm{~Hz}, 1 \mathrm{H}), 7.48(\mathrm{~d}, J=7.9 \mathrm{~Hz}, 2 \mathrm{H}), 7.33(\mathrm{dd}, J=7.7$, $4.8 \mathrm{~Hz}, 1 \mathrm{H}$ ), 7.17 (br. s, 2H), 6.83-6.74 (m, 2H), 5.77 (br. s, $1 \mathrm{H}), 4.88(\mathrm{~d}, J=16.0 \mathrm{~Hz}, 1 \mathrm{H}), 3.91(\mathrm{~d}, J=16.0 \mathrm{~Hz}, 1 \mathrm{H})$, $2.11(\mathrm{~s}, 3 \mathrm{H}), 2.02(\mathrm{~s}, 3 \mathrm{H}), \mathrm{OH}$ and $\mathrm{NH}$ exchanged with $\mathrm{H}_{2} \mathrm{O}$. ${ }^{13} \mathrm{C}$ NMR $\left(100 \mathrm{MHz}, \mathrm{DMSO}-d_{6}\right) *: \delta 149.5,149.0,136.0$, 133.3, 132.2, 130.8, 126.4, 124.1, 59.6, 42.2, 20.2. APSI MS: $489.0\left(\mathrm{M}^{+}+1\right)$. Anal. Calcd for $\mathrm{C}_{25} \mathrm{H}_{21} \mathrm{BrN}_{4} \mathrm{O}_{2}: \mathrm{C}$, 61.36; H, 4.33; N, 11.45\%. Found: C, 61.33; H, 4.30; N, $11.49 \%$.

5-(4-Fluorobenzyl)-3-(2-hydroxy-4,5-dimethylphenyl)4-(4-(methylthio)phenyl)-4,5-dihydropyrrolo[3,4-c]pyrazol-6(1H)-one (5\{5-25-19\}) Yield: 81\%; mp 210-213 ${ }^{\circ} \mathrm{C}$; IR (KBr): 3466-2483 (OH, NH), 1678, 1510, 1464, 1227 , 1092, 1070, $825 \mathrm{~cm}^{-1}$. ${ }^{1} \mathrm{H}$ NMR (400 MHz, DMSO- $d_{6}$ ) $\delta$ 13.25 (br. s, 1H), 9.88 (br. s, 1H), 7.28-6.99 (m, 8H), 6.93 (s, 1H), 6.63 (s, 1H), 5.50 (br. s, 1H), 4.91 (d, J=15.2 Hz, 1H), 3.73 (br. d, $J=14.4 \mathrm{~Hz}, 1 \mathrm{H}$ ), 2.42 (s, 3H), 2.07 (s, $3 \mathrm{H}), 1.98(\mathrm{~s}, 3 \mathrm{H}) .{ }^{13} \mathrm{C}$ NMR (100 MHz, DMSO- $\left.d_{6}\right): \delta 162.8$, $161.8(\mathrm{~d}, J=243.3 \mathrm{~Hz}), 152.3,149.7,138.7,138.4,135.0$, $134.2,133.7,130.1(\mathrm{~d}, J=8.2 \mathrm{~Hz}), 129.5,128.9,127.0$, 126.3, 117.4, $115.78(\mathrm{~d}, J=21.4 \mathrm{~Hz}), 112.4,59.6,43.3$, 19.7, 18.5, 14.7. APSI MS: 474.2 $\left(\mathrm{M}^{+}+1\right)$. Anal. Calcd for $\mathrm{C}_{27} \mathrm{H}_{24} \mathrm{FN}_{3} \mathrm{O}_{2} \mathrm{~S}$ : C, 68.48; H, 5.11; N, 8.87; S, 6.77\%. Found: C, 68.45; H, 5.13; N, 8.81; S, 6.87\%.

3-(5-Chloro-2-hydroxy-4-methylphenyl)-5-(2chlorobenzyl)-4-(4-hydroxy-3- methoxyphenyl)4,5-dihydropyrrolo[3,4-c]pyrazol-6(1H)-one (5\{9-16-20\}) Yield: 79\%; mp 242-244 ${ }^{\circ} \mathrm{C}$; IR (KBr): 3371-2622 (OH, NH), 1679, 1515, 1454, 1264, 1228, 1171, 1141, 1031, $764 \mathrm{~cm}^{-1} .{ }^{1} \mathrm{H}$ NMR (400 MHz, DMSO- $\left.d_{6}\right) \delta 9.07$ (br. s,
1H), 7.47-7.39 (m, 1H), 7.34-7.26 (m, 2H), $7.24(\mathrm{~s}, 1 \mathrm{H})$, 7.19-7.12 (m, 1H), 6.80 (s, 1H), 6.71-6.60 (m, 2H), $6.46(\mathrm{~d}$, $J=7.9 \mathrm{~Hz}, 1 \mathrm{H}), 5.55(\mathrm{~s}, 1 \mathrm{H}), 4.93(\mathrm{~d}, J=16.0 \mathrm{~Hz}, 1 \mathrm{H}), 4.00$ (d, $J=16.0 \mathrm{~Hz}, 1 \mathrm{H}), 3.64$ (s, 3H), 2.18 (s, 3H); another $\mathrm{OH}$ and $\mathrm{NH}$ exchanged with $\mathrm{H}_{2} \mathrm{O} .{ }^{13} \mathrm{C}$ NMR (100 MHz, DMSO$\left.d_{6}\right)^{*}: \delta 147.9,146.9,137.0,134.9,132.5,129.9,129.8$, 129.4, 128.5, 127.8, 123.5, 120.3, 118.6, 116.2, 112.4, 60.4, 55.9, 42.1, 19.9. APSI MS: $510.0\left(\mathrm{M}^{+}+1\right)$. Anal. Calcd for $\mathrm{C}_{26} \mathrm{H}_{21} \mathrm{Cl}_{2} \mathrm{~N}_{3} \mathrm{O}_{4}$ : C, 61.19; H, 4.15; Cl, 13.89; N, 8.23\%. Found: C, 61.16; H, 4.19; Cl, 13.97; N, 8.31\%.

3 - ( 5 - Chloro-2 - hydroxy-4-methylphenyl)4 - (3-chlorophenyl)-5-(3-hydroxypropyl)-4,5dihydropyrrolo[3,4-c]pyrazol-6(1H)-one (5\{9-21-8\}) Yield: 80\%; mp 275-277 ${ }^{\circ} \mathrm{C}$; IR (KBr): 3479-2513 (OH, NH), 1674, 1466, 1397, 1297, 1096, 1071, $704 \mathrm{~cm}^{-1}$. ${ }^{1} \mathrm{H}$ NMR (400 MHz, DMSO- $d_{6}$ ) $\delta 13.45$ (br. s, $\left.1 \mathrm{H}\right), 10.55$ (br. s, 1H), 7.37-7.32 (m, 2H), $7.30(\mathrm{~s}, 1 \mathrm{H}), 7.25(\mathrm{~s}, 1 \mathrm{H}), 7.13-7.05(\mathrm{~m}$, 1H), 6.83 (br. s, 1H), 5.85 (s, 1H), 4.47 (br. s, 1H), 3.67 (dt, $J=14.1,7.2 \mathrm{~Hz}, 1 \mathrm{H}), 3.40-3.35$ (m, 2H), 2.75 (ddd, $J=14.1$, 8.2, 5.9 Hz, 1H), 2.19 (s, 3H), 1.72-1.60 (m, 1H), 1.60-1.48 $(\mathrm{m}, 1 \mathrm{H}) .{ }^{13} \mathrm{C}$ NMR $\left(100 \mathrm{MHz}, \mathrm{DMSO}-d_{6}\right) *: \delta 153.3,137.1$, 133.7, 131.2, 128.8, 128.2, 126.6, 123.5, 118.7, 59.6, 58.8, 38.2, 31.5, 19.9. APSI MS: $432.0\left(\mathrm{M}^{+}+1\right)$. Anal. Calcd for $\mathrm{C}_{21} \mathrm{H}_{19} \mathrm{Cl}_{2} \mathrm{~N}_{3} \mathrm{O}_{3}$ : C, 58.35; H, 4.43; Cl, 16.40; N, 9.72\%. Found: C, 58.32; H, 4.40; Cl, 16.48; N, 9.79\%.

Supplementary Information The online version contains supplementary material available at https://doi.org/10.1007/s11030-021-10234-2.

Acknowledgements Authors are grateful grateful to ENAMINE Ltd., Kyiv for financial support and for providing NMR spectra.

\section{References}

1. Welsch ME, Snyder SA, Stockwell BR (2010) Privileged scaffolds for library design and drug discovery. Curr Opin Chem Biol 14(3):347-361. https://doi.org/10.1016/j.cbpa.2010.02.018

2. Rodrigues T, Reker D, Schneider P, Schneider G (2016) Counting on natural products for drug design. Nature Chem 8(6):531541. https://doi.org/10.1038/nchem.2479

3. Schreiber SL (2000) Target-oriented and diversity-oriented organic synthesis in drug discovery. Science 287(5460):19641969. https://doi.org/10.1126/science.287.5460.1964

4. Zhang L, Zheng M, Zhao F, Zhai Yu, Liu H (2014) Rapid generation of privileged substructure-based compound libraries with structural diversity and drug-likeness. ACS Comb Sci 16(4):184-191. https://doi.org/10.1021/co4001309

5. Pelish HE, Westwood NJ, Ya F, Kirchhausen T, Shair MD (2001) Use of biomimetic diversity-oriented synthesis to discover galanthamine-like molecules with biological properties beyond those of the natural product. J Am Chem Soc 123(27):6740-6741. https://doi.org/10.1021/ja016093h

6. Schreiber SL (2003) The small molecule approach to biology. Chem Eng News 81:51-61. http://portals.broadinstitute.org/ chembio/lab_schreiber/pubs/pdffiles/331.pdf 
7. Edwards AM, Howell JBL (2000) The chromones: history, chemistry and clinical development. A tribute to the work of Dr R. E. C. Altounyan. Clin Exp Allergy 30(6):756-774. https:// doi.org/10.1046/j.1365-2222.2000.00879.x

8. Wilk W, Waldmann H, Kaiser M (2009) $\gamma$-Pyrone natural products - a privileged compound class provided by nature. Bioorg Med Chem 17(6):2304-2309. https://doi.org/10.1016/j.bmc. 2008.11.001

9. Khadem Sh, Marles RJ (2012) Chromone and flavonoid alkaloids: occurrence and bioactivity. Molecules 17(1):191-206. https://doi.org/10.3390/molecules17010191

10. Silva CFM, Batista VF, Pinto DCGA, Silva AMS (2018) Challenges with chromone as a privileged scaffold in drug discovery. Exp Opinion Drug Disc 13(9):795-798. https://doi.org/10.1080/ 17460441.2018.1494720

11. Reis J, Gaspar A, Milhazes N, Borges F (2017) Chromone as a privileged scaffold in drug discovery: recent advances. J Med Chem 60(19):7941-7957. https://doi.org/10.1021/acs.jmedc hem.6b01720

12. Gaspar A, Matos MJ, Garrido J, Uriarte Eu, Borges F (2014) Chromone: a valid scaffold in medicinal chemistry. Chem Rev 114(9):4960-4992. https://doi.org/10.1021/cr400265z

13. Keri RS, Budagumpi S, Pai RK, Balakrishna RG (2014) Chromones as a privileged scaffold in drug discovery: a review. Eur J Med Chem 78:340-374. https://doi.org/10.1016/j.ejmech.2014. 03.047

14. Ya Z, Zhang X, Yao R, Wen YuCh, Huang J, Xu X (2016) 1,3-Dipolar Cycloaddition of alkyne-tethered N-tosylhydrazones: synthesis of fused polycyclic pyrazoles. J Org Chem 22:1107211080. https://doi.org/10.1021/acs.joc.6b02076

15. Yadav R, Parvin T, Panday AK, Choudhury LH (2021) Synthesis of styryl-linked fused dihydropyridines by catalyst-free multicomponent reactions. Mol Divers. https://doi.org/10.1007/ s11030-021-10216-4

16. Yavari I, Sheykhahmadi J (2021) TFA-mediated synthesis of functionalized pyrano[2,3-c]pyrazoles from pyrazol-3-ones, active carbonyl compounds and tert-BuOH. Mol Divers. https://doi.org/10. 1007/s11030-021-10200-y

17. Santos CMM, Silva VLM, Silva AMS (2017) Synthesis of chromone-related pyrazole compounds. Molecules 22(10):1665. https://doi.org/10.3390/molecules22101665

18. Malets YS, Moskvina VS, Grygorenko OO, Brovarets VS (2019) Synthesis of azachromones and azachromanones. Chem Heterocycl Comp. https://doi.org/10.1007/s10593-019-02570-x

19. Miyake $\mathrm{Y}$, Mochizuki M, Ito C, Itoigawa M, Osawa T (2008) Antioxidative pyranonigrins in rice mold starters and their suppressive effect on the expression of blood adhesion molecules. Biosci Biotechnol Biochem 72(6):1580-1585. https://doi.org/10. 1271/bbb. 80077

20. Hiort J, Maksimenka K, Reichert M, Perović-Ottstadt S, Lin WH, Wray V, Steube K, Schaumann K, Weber H, Proksch P, Ebel R, Müller WE, Bringmann G (2004) New natural products from the sponge-derived fungus Aspergillus niger. J Nat Prod 67(9):15321543. https://doi.org/10.1021/np030551d

21. Schlingmann G, Taniguchi T, He H, Bigelis R, Yang HY, Koehn FE, Carter GT, Berova N (2007) Reassessing the structure of Pyranonigrin. J Nat Prod 70(7):1180-1187. https://doi.org/10. 1021/np070175n

22. Kishimoto S, Tsunematsu Y, Sato M, Watanabe K (2017) Elucidation of biosynthetic pathways of natural products. Chem Rec 17(11):1095-1108. https://doi.org/10.1002/tcr.201700015

23. Riko R, Nakamura H, Shindo K (2014) Studies on pyranonigrinsisolation of pyranonigrin $\mathrm{E}$ and biosynthetic studies on pyranonigrin A. J Antibiot 67:179-181. https://doi.org/10.1038/ja.2013.91

24. Rao P, Shukla A, Parmar P, Rawal RM, Patel B, Saraf M, Goswami D (2020) Reckoning a fungal metabolite, Pyranonigrin
A as a potential Main protease $\left(\mathrm{M}^{\mathrm{pro}}\right)$ inhibitor of novel SARSCoV-2 virus identified using docking and molecular dynamics simulation. Biophysical Chem. https://doi.org/10.1016/j.bpc.2020. 106425

25. Sarabu R, inventor; Hoffmann-La Roche, applicant. 3-Oxo-3,9-dihydro- $1 H$-chromeno[2,3-c]pyrroles as glucokinase activators. Canadian Patent Application CA2801168A1. 2011 Dec 22

26. Sidhu PS, Mosier PD, Zhou Q, Desai UR (2013) On scaffold hopping: challenges in the discovery of sulfated small molecules as mimetics of glycosaminoglycans. Bioorg Med Chem Lett 23(1):355-359. https://doi.org/10.1016/j.bmcl.2012.10.079

27. Vydzhak RN, Panchishin SY (2006) Simple synthesis of 1,2-diaryl-1,2-dihydrochromeno[2,3-c]pyrrole-3,9-diones. Russ J General Chem 76:1681-1682. https://doi.org/10.1134/S107036320 6100331

28. Vydzhak RN, Panchishin SY (2008) Synthesis of 2-alkyl-1-aryl1,2-dihydrochromeno[2,3-c]pyrrole-3,9-dione derivatives. Russ J General Chem 78:2391-2397. https://doi.org/10.1134/S1070 363208120165

29. Vydzhak RN, Panchishin SY (2010) Synthesis of 1-aryl-2-[2(dimethylamino)ethyl]-1,2-dihydrochromeno[2,3-c]pyrrole3,9-diones and their analogs. Russ J General Chem 80:323-329. https://doi.org/10.1134/S1070363210020222

30. Vydzhak RN, Panchishin SY (2008) Synthesis of 2-phenyl5,6-dihydropyrano[2,3-c]pyrrole-4,7-dione derivatives. Russ J General Chem 78:1641-1642. https://doi.org/10.1134/S1070 363208080331

31. Ellis GP, Romney-Alexander TM (1985) Benzopyrones. Part 20. Synthesis of new tri- and tetracyclic chromen-4-ones. Chem Inform 16(18):206. https://doi.org/10.1002/chin.198518206

32. Vydzhak RN, Panchishin SY (2011) Synthesis of 1,2-dihydrochromeno[2,3-c]pyrrole-3,9-diones spiro derivatives. Russ J General Chem 81:617-619. https://doi.org/10.1134/S1070 363211030340

33. Vydzhak RN, Kachaeva MV, Pilyo SG, Moskvina VS, Shablykina OV, Kozytskiy AV, Brovarets VS (2020) Three-component cyclization as an approach to a combinatorial library of $2 H$-spiro-[chromeno[2,3-c]pyrrole-1,3'-indoline]-2',3,9-triones. Ukr Bioorg Acta 15(1):26-33. https://doi.org/10.15407/bioor ganica2020.01.026

34. Neo AG, Garrido L, Dнаz J, Marcaccini S, Marcos CF (2012) Furo $[3,4-b]$ chromones, and not pyrano $[3,4-b]$ chromones, are obtained by the reaction of 3 -formylchromones with isocyanides. Synlett 23(15):2227-2230. https://doi.org/10.1055/s0032-1317032

35. Panja SK, Maiti S, Banerjee S, Bandyopadhyay C (2010) Onepot synthesis of pyrano[3,4- $b]$ chromones from chromone-3-carbaldehyde. Synlett 13:1909-1914. https://doi.org/10.1055/s0030-1258496

36. Panja SK, Maiti S, Drew MGB, Bandyopadhyay C (2011) Onepot three component reaction involving cyclohexyl isocyanide for the synthesis of furo [3, 4-b] chromenes. J Chem Res. https://doi.org/10.3184/174751911X13015945166625

37. Teimouri MB (2011) Serendipitous stereoselective synthesis of brand-new fluorescent dyes: (1Z)-3-(alkylimino)-1-[(chromone3-yl)methylene]-1,3-dihydro-9H-furo[3,4- $b$ ] chromen-9-onetype fluorophores with blue fluorescence emission properties. Tetrahedron 67(10):1837-1843. https://doi.org/10.1016/j.tet. 2011.01.033

38. Teimouri MB, Asnaashari B (2014) One-pot synthesis of 5-(furo[3,4- $b$ ]chromenyl)-5-hydroxybarbiturates via a threecomponent cascade reaction. Tetrahedron Lett 55(14):2249_ 2252. https://doi.org/10.1016/j.tetlet.2014.02.075

39. Terzidis MA, Tsiaras VG, Drosos NM, Kasapidou PM, Stephanidou-Stephanatou J, Tsoleridis CA, Buth G, Kostakis GE (2014) Chromeno[2,3-c]pyrroles by one-pot multicomponent domino 
addition-amination reaction. Tetrahedron Lett 55(41):56015604. https://doi.org/10.1016/j.tetlet.2014.08.048

40. Cioc RC, Ruijter E, Orru RVA (2014) Multicomponent reactions: advanced tools for sustainable organic synthesis. Green Chem 16(6):2958-2975. https://doi.org/10.1039/C4GC00013G

41. Tashrifi Z, Mohammadi-Khanaposhtani M, Hamedifar H, Larijani B, Ansari S, Mahdavi M (2020) Synthesis and pharmacological properties of polysubstituted 2-amino- $4 H$-pyran3-carbonitrile derivatives. Mol Divers 24:1385-1431. https:// doi.org/10.1007/s11030-019-09994-9

42. Brahmbhatt GC, Sutariya TR, Atara HD, Parmar NJ, Gupta VK, Lagunes I, Padrón JM, Murumkar PR, Yadav MR (2020) New pyrazolyl-dibenzo[ $b$, e $][1,4]$ diazepinones: room temperature one-pot synthesis and biological evaluation. Mol Divers 24:355-377. https://doi.org/10.1007/s11030-019-09958-z

43. Wender PA (2014) Toward the ideal synthesis and molecular function through synthesis-informed design. Nat Prod Rep 31(4):433-440. https://doi.org/10.1039/C4NP00013G
44. Frasinyuk MS, Khilya VP (1999) Preparation and reactions of isoflavone heteroanalogs (a review). Chem Heterocycl Compd 35:3-22. https://doi.org/10.1007/BF02251655

45. Ibrahim MA, Ali TE, Alnamer YA, Gabr YA (2010) Synthesis and chemical reactivity of 2-methylchromones. ARKIVOC. https:// doi.org/10.3998/ark.5550190.0011.103

46. Sosnovskikh VY (2003) Synthesis and reactions of halogen-containing chromones Russ. Chem Rev 72(6):489-516. https://doi. org/10.1070/RC2003v072n06ABEH000770

47. Plaskon AS, Grygorenko OO, Ryabukhin SV (2012) Recyclizations of 3-formylchromones with binucleophiles. Tetrahedron 68(13):2743-2757. https://doi.org/10.1016/j.tet.2012.01.077

48. Ibrahim MA, El-Kazak AM (2019) Ring opening and recyclization reactions with chromone-3-carbonitrile. J Heterocycl Chem 56(3):1075-1085. https://doi.org/10.1002/jhet.3495

Publisher's Note Springer Nature remains neutral with regard to jurisdictional claims in published maps and institutional affiliations. 